\title{
IntechOpen
}

\section{Selected Aspects of \\ Non-Profit Organisations}

Edited by Tatjana Horvat

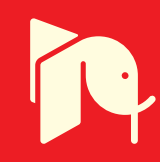





\section{Selected Aspects of Non-Profit Organisations}

Edited by Tatjana Horvat 

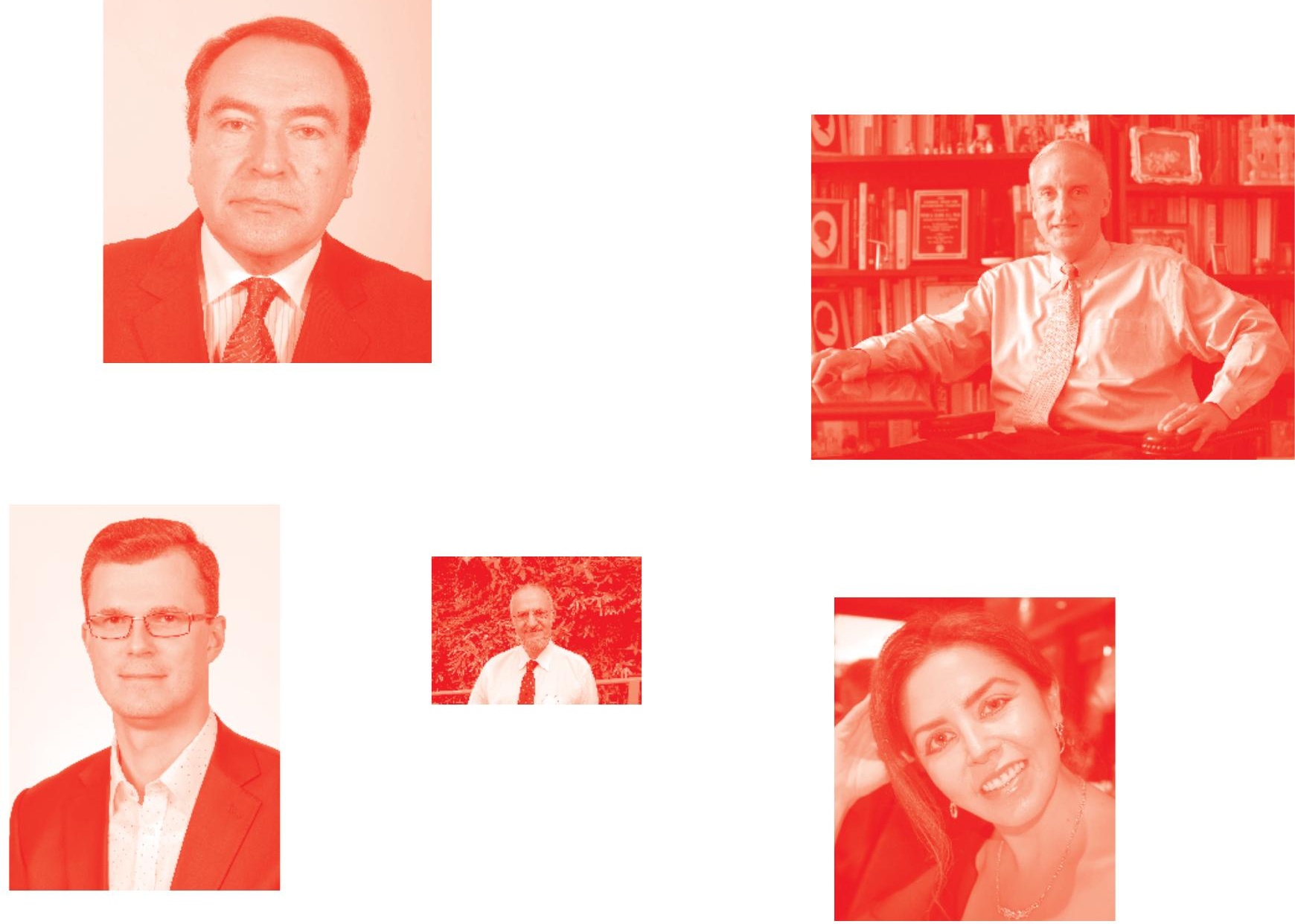

Supporting open minds since 2005
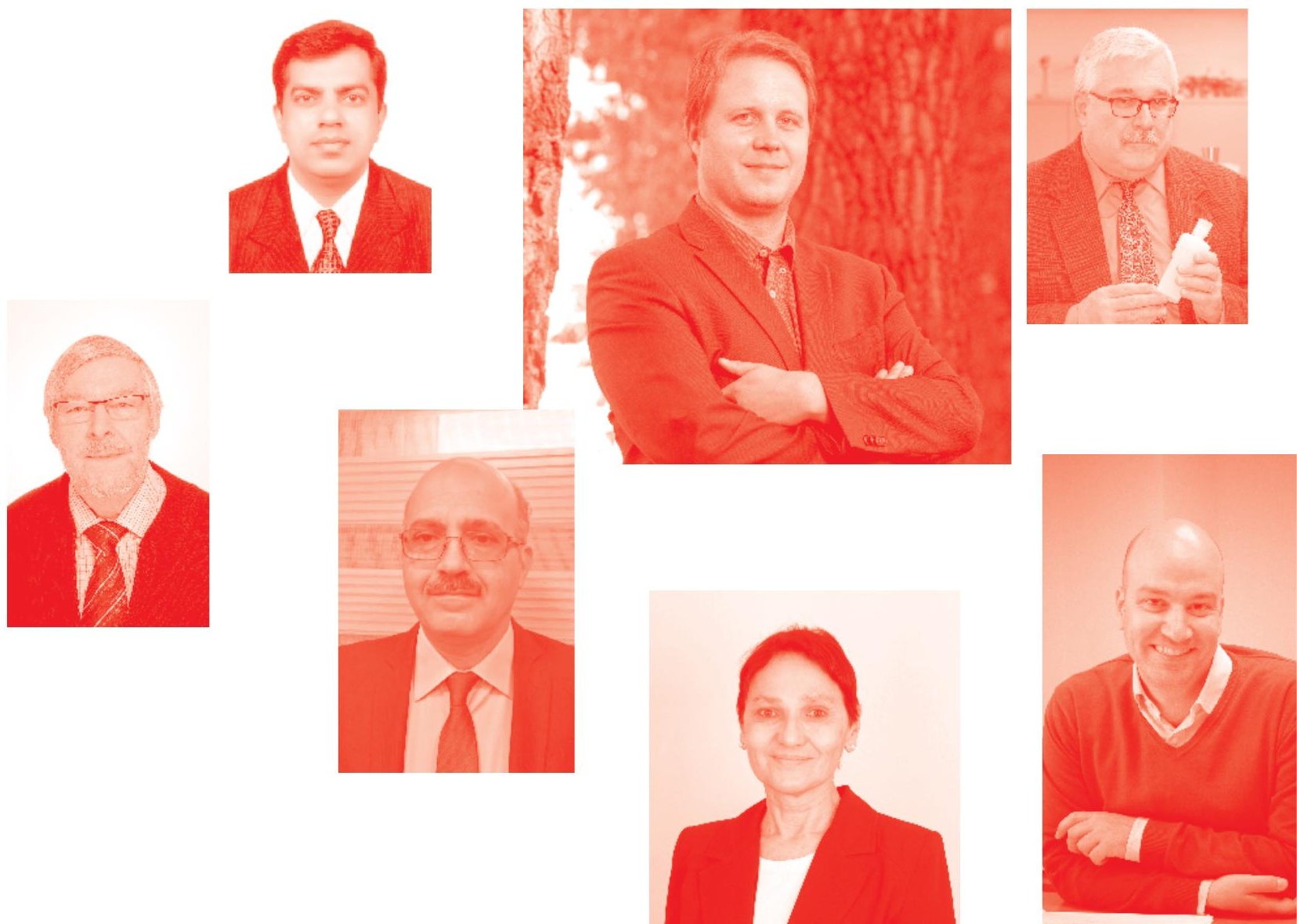
Selected Aspects of Non-Profit Organisations http : //dx. doi. org/10.5772/intechopen. 78098

Edited by Tatjana Horvat

\section{Contributors}

Bernadene Erasmus, Tatjana Horvat, Vito Bobek, Mária Murray Svidroňová, Mohammed Aboramadan

(๑) The Editor(s) and the Author(s) 2020

The rights of the editor(s) and the author(s) have been asserted in accordance with the Copyright, Designs and Patents Act 1988. All rights to the book as a whole are reserved by INTECHOPEN LIMITED. The book as a whole (compilation) cannot be reproduced, distributed or used for commercial or non-commercial purposes without INTECHOPEN LIMITED's written permission. Enquiries concerning the use of the book should be directed to INTECHOPEN LIMITED rights and permissions department (permissions@intechopen.com).

Violations are liable to prosecution under the governing Copyright Law .

\section{(cc) BY}

Individual chapters of this publication are distributed under the terms of the Creative Commons Attribution 3.๑ Unported License which permits commercial use, distribution and reproduction of the individual chapters, provided the original author(s) and source publication are appropriately acknowledged. If so indicated, certain images may not be included under the Creative Commons license. In such cases users will need to obtain permission from the license holder to reproduce the material. More details and guidelines concerning content reuse and adaptation can be found at http : //www . intechopen . com/copyright-policy . html .

\section{Notice}

Statements and opinions expressed in the chapters are these of the individual contributors and not necessarily those of the editors or publisher. No responsibility is accepted for the accuracy of information contained in the published chapters. The publisher assumes no responsibility for any damage or injury to persons or property arising out of the use of any materials, instructions, methods or ideas contained in the book.

First published in London, United Kingdom, 2020 by IntechOpen IntechOpen is the global imprint of INTECHOPEN LIMITED, registered in England and Wales, registration number: 11086078 , 7th floor, 10 Lower Thames Street, London,

EC3R 6AF, United Kingdom

Printed in Croatia

British Library Cataloguing-in-Publication Data

A catalogue record for this book is available from the British Library

Additional hard and PDF copies can be obtained from orders@intechopen.com

Selected Aspects of Non-Profit Organisations

Edited by Tatjana Horvat

p. cm.

Print ISBN 978-1-78985-627-9

Online ISBN 978-1-78985-628-6

eBook (PDF) ISBN 978-1-78985-559-3 


\section{We are IntechOpen, \\ the world's leading publisher of Open Access books}

\section{Built by scientists, for scientists}

\section{$4,600+$}

Open access books available

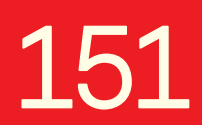

Countries delivered to

$119,000+$

International authors and editors

Our authors are among the

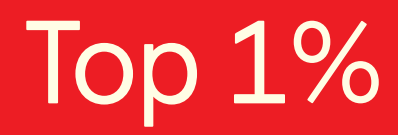

most cited scientists
$135 \mathrm{M}+$

Downloads

\section{$12.2 \%$}

Contributors from top 500 universities

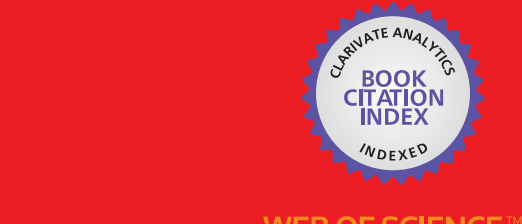

Selection of our books indexed in the Book Citation Index in Web of Science ${ }^{\mathrm{TM}}$ Core Collection (BKCI)

\section{Interested in publishing with us? \\ Contact book.department@intechopen.com}

Numbers displayed above are based on latest data collected.

For more information visit www.intechopen.com 



\section{Meet the editor}

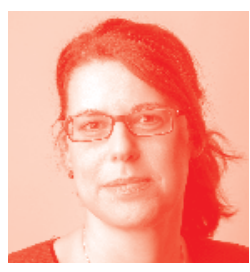

Dr. Tatjana Horvat is an expert in auditing, accounting, financing, taxes, and public budgets for companies and public institutions, being engaged as an expert in several countries. She is also a Certified State Internal Auditor (licensed by Ministry of Finance RS) and a Certified Internal Auditor for Business Sector and Certified Accountant (licensed by Slovenian Institute of Auditors). At the Ministry of Justice of Slovenia, she is a member of examination boards for court expert candidates and judicial appraisers in the following areas: economy/finance, valuation of companies, and forensic investigation of economic operations/forensic accounting. She also works as an associate professor for accounting and auditing. For many years, she has served as the president of jury for the best annual (financial) report of big companies and financial institutions as well as the best CFO. At the most important daily business newspaper Finance in Slovenia (Swedish ownership), she is the editor and head of area for business, finance, and tax related articles as well as educational programs. She is the standard-setter for transparent financial reporting of big companies, financial institutions, and educational institutions. She has written more than 300 papers, articles, books, and manuals and she has been a guest of many international scientific and business conferences. At the National School of Leadership in Education she is involved as a professional in European projects for effective financial leadership in educational institutions. 



\section{Contents}

Preface

Section 1

Introduction

Chapter 1

Introductory Chapter: Selected Aspects of Non-Profit Organisations

by Tatjana Horvat

\section{Section 2}

Theoretical Framework of Non-Profit Organisations

Chapter 2

Factors that Drive Volunteerism in Nonprofit Organizations: A Theoretical Framework

by Mohammed Aboramadan

\section{Section 3}

Governments and Non-Profit Organisations

Chapter 3

On Relations between Government and Non-profits: The Case of Slovakia by Mária Murray Svidroňová

\section{Section 4}

Financial Aspects of Non-Profit Organisations

Chapter 4

Planning the Audit of Financial Resources in a Non-Profit Organization by Tatjana Horvat and Vito Bobek

\section{Section 5}

Recruitment in Non-Profit Organisations

Chapter 5

Connect-Active: An Innovative Recruitment Model for Potential Volunteers in Nonprofit Organizations

by Bernadene Erasmus and Peter J. Morey 



\section{Preface}

Not-for-profit organisations (non-profits) are increasing their influence and are becoming an increasingly important partner both to governments and international organisations. Many governments around the world want to maintain and strengthen partnerships with non-profits or the so-called 'third sector', which is why they pay particular attention to it, not just at the declarative level. Taking all the changes that have taken place in the last decade into account means that non-profits have to adapt to those changes, that is, they have to organise themselves properly, they have to adapt their programs, and obtain adequate resources - or in other words, they have to adapt their strategies to the new situation.

This book is organised into four sections, in addition to the Introduction.

The first section deals with the theoretical framework of non-profit organisations, examining and reviewing the factors that drive volunteering in non-profits. It follows a multidisciplinary approach in defining and examining the factors that drive individuals to volunteer in non-profits. The section provides a theoretical framework on how different factors are associated with volunteerism in non-profits. It also provides analysis of the volunteerism concept by looking at factors that drive volunteerism from diverse standpoints, e.g. an economic, sociological, psychological, and managerial standpoint. Most notably, empathy and extraversion proved to be highly correlated with volunteerism. Mediating factors could be also unveiled, such as "principle of care" for the case of empathy. Agreeableness is also linked to volunteer work but is not typical of all volunteers. Other variables such as openness to experience, solidarity, and personal identity were given equal importance. We also looked at the economic theory of volunteerism that speculates that individuals are self-interested when they decide to volunteer. Moreover, we considered religion and its impact on individuals' willingness to volunteer. Then, we turned our focus to demographical factors such as gender, race, age, and education to provide a fuller and more solid answer.

\section{The second section focuses on the relationships between governments and} non-profit organisations by dealing with the question: does privatisation of state-owned enterprise allow for efficiency improvement of the firm, and provides the impetus for indirect entry regulation of private entrants? When privatisation occurs, three major interacting effects determine the optimal privatisation level in a mixed market: welfare-reducing effect, output substitution effect, and efficiencyenhancing effect. Given these effects, this section examines in depth that, under certain conditions, partial privatisation in a mixed duopoly is a win-win-win policy for the social welfare, state-owned, and private firms. It implies that the partially privatised firm concerns not only firm's profitability, but social responsibility. The efficiency-enhancing effect, if weak, will impel the state-owned firm to release more stock shares at the optimum amount, and then bring about a welfareimproving, profit-increasing situation. The study further demonstrates the effects of the magnitude of the efficiency-enhancing effect on the level of social welfare and the firms' profits. 
The third section is on financial aspects of non-profit organisations and is devoted to internal auditing of non-profits. which represents the first line of defence against inadequate use of non-profit's funding sources. In the European legal system, the purpose of a non-profit is to meet the needs of stakeholders. An organisation cannot divide the generated profits among the members, but aims at extending, increasing, and improving the quality of services and goods. Non-profits, due to their nature, are not able to acquire their own sources of financing which is why they largely depend on subsidies, grants, membership fees etc. Therefore, the correct use of these sources is more important. One way of checking the use of sources of financing is an internal audit, which must be carefully planned. The purpose of this section is to present planning process for an internal audit for a non-profit organisation. The case study analysis of a non-profit organisation was performed using the analysis of secondary written documents, unstructured interviews, and a selection of a non-statistical sample of documents.

The fourth section is on recruitment of non-profit organisations and it deals with some aspects of volunteerism. The study of volunteerism has yielded different theoretical and conceptual models. It spans across fundamentally different disciplines, serves organisations in a wide variety of industries, and changes from one country to another. There are several factors that drive volunteerism from an economic, sociological, psychological, and managerial standpoint. Literature considering the relationship between personality traits and volunteer work was meticulously studied. The economic theory of volunteerism speculates that individuals are self-interested when they decide to volunteer. Finally, the perspective shifted from the level of the individual to that of the organisation to see how management affect the willingness to volunteer.

Finally, I would like to express my gratitude to IntechOpen publishing for appointing me as the editor of this book. I am thankful for their trust that I could provide the required expertise and technical assistance. We worked together as a team and managed to find some great colleagues that contributed to this book. A big "thank you" to the authors for their great contributions in form of chapters to this book; We all believe that it will be an asset to the non-profit community. Last but not least, I wish to thank the technical reviewers and colleagues at IntechOpen for their great work.

Tatjana Horvat Professor, University of Primorska, Faculty of Management, Ljubljana, Slovenia 
Section 1

\section{Introduction}





\title{
Introductory Chapter: Selected Aspects of Non-Profit Organisations
}

\author{
Tatjana Horvat
}

\section{Introduction}

The term non-profit organisation represents two types of organisations. One is public non-profit organisations founded by public institutions. Their mission is to implement the public interest. On the other hand, we have private non-profit organisations founded by private natural and/or legal persons whose mission is pursuing a common and/or public interest. Both public and common interest represent the legitimate operationalisation of the general social interest ([1], p. 324).

According to Salamon [2], over the past 25 years, we have witnessed a great expansion of philanthropy, volunteerism and civil society organisations around the world. Consequently, interest in academic research in the field has increased. Most academic and research work in the field is, of course, in the field of sociological sciences [3].

In economics, we can approach topics through interest theory. Tavčar ([4], p. 259) mentions that the dual aspect is characteristic of any organisation. The organisation as an instrument for achieving the set goals of individuals and the organisation as a community of interests characterised by complexity where the success of the organisation is the consistency of action for the purpose of establishment, taking into account the interests of external and internal stakeholders. The character of an organisation is therefore a reflection of the attitude of important stakeholders. The areas covering stakeholders' interest, their accountability and how they influence the development of non-governmental organisation, are less extensively explored in the scientific literature. As Candler and Dumont [5] have pointed out, there is no shortage of research on the non-profit sector; what is there is a modesty of literature that directly addresses the issue of the interests of internal and external stakeholders on non-profit organisation performance.

When we discuss development, we inadvertently touch the area of success. The importance of performance measurement in non-profit organisations has already been described by Kaplan [6] who has transferred the model of balanced indicators to the level of non-profit organisations. This model shows how organisations are aware of the link between the non-financial and intangible dimensions of performance measurement and the implications for cash flow [7]. Many others also place considerable weight on the performance measurement in non-profit organisations [8-13]. Performance measurement in for-profit organisations is primarily about creating financial value for its owners [14], while measuring performance in non-profits has two goals in particular: demonstrating its value to stakeholders and improving organisational performance by learning and evaluating its programmes or services, and comparing with others through internal reporting [15]. Therefore, 
it can be said that the success of non-profit organisations is not essential, but it is important for their operation and survival.

Rakar et al. ([16], p. 14) describe private non-profit organisations as part of a civil society, defined as a space outside the family, state and market created by individual and group actions, organisations and institutions, with the aim of pursuing common interests. They represent an important instrument of democratisation and pluralisation of relations, expansion of individual possibilities and free choice of individuals, and increase of active participation in modern society ([17], p. 153).

Costa et al. ([18], p. 473) consider that non-profit organisations have emerged as an important factor in promoting social values and integration, in creating global civil society that can often influence practices, and in national and international policies.

Vrečko ([19], p. 20) attributes a special role to the importance of non-profit organisations. According to him, non-governmental organisations are one of the three main pillars of modern society, with completely their own identity and social function, independent of the state and economic sectors.

Non-profit organisations also represent a particular type of cultural and institutional base. Because their commitment is a particular social mission, their members are primarily interested in the organisational mission and desire to contribute to making the world even better. Non-profit organisations are also less hierarchical than other institutions [20,21].

Kolarič ([22], p. 29) emphasises that non-governmental organisations are among non-profit organisations, which are mostly not established for profit, but to assist in the continuous provision of services and goods for the successful functioning of society. It follows that the reason for the existence of non-profit organisations is to act in the general social interest, that is, to act for generally socially beneficial purposes. Nevertheless, Salamon and Anheier ([23], p. 2) argue that non-profit organisations remain a 'lost continent' on the map of modern societies, invisible to most political and economic actors, media and even many individuals who work in it.

Financing commercialisation requires that employees of non-profit organisations also have similar skills in the field of business-organisational sciences as their counterparts in the private sector. Without these, they would have been in the process of acquiring alternative financial resources quite unsuccessful. The necessary knowledge may be obtained in part from members of the supervisory boards in private sector, from students of business-organisational sciences and volunteers from successful for-profit business.

Non-profit organisations can also form networks and alliances with the for-profit sector through which they seek to gain the missing complementary knowledge and experience. However, there is a general belief that greater commercialisation cannot be based solely on the advice and assistance of external surveillance of Supervisory Board members, consultants and partners.

It is necessary to recruit their own (internal) professional staff. This, in turn, entails some human resource management problems. By recruiting qualified professionals coming from the economy, conflicts arise in corporate culture and rewarding of managers. Senior non-profit managers need to anticipate potential conflicts and find ways to turn them into creatively healthy tension. One option is to separate the profit-oriented activities of non-profit organisations that require more business-organisational skills from other non-profit activities. Such reorganisation can bear fruit only if the activities can be separated in such a way that their daily interaction is unnecessary. However, even in this case, employees of non-profit philanthropic activities may follow the activities of their more market-oriented colleagues with envy and hatred. It is difficult to establish different levels of pay for 
employees with the same education and work experience. Such a payment system can also entail a significant increase in costs. On the other hand, the absence of such a payment scheme hinders the acquisition of qualified staff, which can greatly increase non-profit organisations' revenue and reduce costs.

Due to the emphasis on commercialisation, the government requires that the companies it finances at all levels (local, regional, national) respect the principles of efficiency, economy and competitiveness as applied to private commercial enterprises. As a result, major non-profit voluntary organisations in the US have recruited one-third of senior managers from the for-profit sector [24].

People with business skills are replacing past employees who have acted on a more amateur and less professional basis. Some non-profit organisations think this is right and others that it is difficult to involve users and people from the local environment in the implementation of the activities due to new trends. Increasing professional skills of employees also require an increasingly risky environment. The demands for innovation, flexibility and diversification are increasing. As a result, the old bureaucratic habits of work and leadership need to be abandoned. This is particularly conditioned by the shift from stable state funding to the search for private sources.

In order to ensure the effective use of non-profit organisations' funds, effective internal and external control is crucial. This is not possible without setting appropriate accounting standards that may again be specific to specific types of non-profit organisations by organisational form (societies, institutes, etc.) and by activity (health, education, etc.). Thus, for example, the American National Association of College and University Business Officers reached an agreement with the state financial administration on accounting principles and reporting. Since that association issued the first guide to recommended accounting practices and subsequently updated it regularly and if necessary, they argue, these accounting principles have become widely accepted standards, also recognized by the national body of colleges and universities (Audits of Colleges and Universities) and taught at US universities through specialized accounting programs for university institutions [25].

On the basis of comparable financial statements, it is also possible to make a comparative assessment of the funds used. It is possible to set appropriate and acceptable standards for financing the activities of non-profit organisations. The comparative assessment of the use of funds is based on statistical analyses of the institutions, which are grouped by activity type, size, geographical location and scope of the programme. Normally, groups with similar characteristics are analysed to find out how much they are worth, for example, the average cost per student of a higher education organisation. In smaller countries, the problem may be that there are fewer non-profit organisations of the same type. Therefore, it is necessary to compare different organisations (e.g., different faculties of social sciences, rather than, say, several faculties of economics, since they simply do not exist). The estimate of the required financial resources will — of course-be based on the average, but will have to take into account the objectively conditioned specificities of each individual institution.

Contemporary international guidelines for the development of non-profit organisations show that they are of importance and that the role of non-profit organisations has been recognised by virtually all developed countries. Therefore, in the last two decades of the twentieth century, one could notice a real boom in non-profit organisations, most notably in a form of accelerated partnerships between them and the government. This is reflected in the involvement of nonprofit organisations in decision-making processes as well as in their wider process of inclusion into the network of service providers of public interest (public networks). 
In the Member States of the European Union, non-profit organisations are heavily involved in the functioning of the government, especially in the fields of education (Belgium, Ireland), healthcare (Netherlands), social welfare (Austria, France, Germany, Spain) and culture and sports (Czech Republic, Hungary, Slovakia). As a result, they employ on average $5.42 \%$ of the active population. Their close cooperation with the government is also reflected in the share of revenues from public sources, since this in the Member States of the European Union accounts for an average of 58\% of all non-profit organisations' revenues and their state revenues. Publicly funded programs spend an average of $2.20 \%$ of national GDP ([26], p. 2). In the field of volunteering, a direction of development is evident regarding corporate social responsibility, the development of corporate volunteering and other innovative forms of volunteering that follow rapid changes in society.

\section{Author details}

Tatjana Horvat

Faculty of Management, University of Primorska, Ljubljana, Slovenia

*Address all correspondence to: tatjana.horvat@fm-kp.si

\section{IntechOpen}

(C) 2020 The Author(s). Licensee IntechOpen. This chapter is distributed under the terms of the Creative Commons Attribution License (http://creativecommons.org/licenses/ by/3.0), which permits unrestricted use, distribution, and reproduction in any medium, provided the original work is properly cited. (cc) BY 


\section{References}

[1] Monnier L, Bernard T. Mutations structurelles et interet general: vers quels nouveaux paradigmes pour l'economie publique, sociale et cooperative? Pariz/Bruselj: Ciriec International/DeBoeck Université; 1997

[2] Salamon LM. Putting the civil society sector on the economic map of the world. Annals of Public and Cooperative Economics. 2010;81(2):167-210

[3] DiMaggio PJ, Anheier HK. The sociology of non-profit organisations and sectors. Annual Review of Sociology. 1990;16:137-159

[4] Tavčar MI. Management in Organizacija: Sinteza Konceptov Organizacije Kot Instrumenta in Kot Skupnosti Interesov. Koper: Fakulteta za Management; 2009

[5] Candler G, Dumont G. A nonprofit accountability framework. Canadian Public Administration. 2010;53(2):259-279

[6] Kaplan RS. Strategic performance measurement and management in non-profit organizations. Nonprofit Management and Leadership 2001;11(3):353-370

[7] Neely A, Bernard M, Goran R, Stephen P, Oliver G. Towards the third generation of performance measurement. Controlling. 2003;15(3-4):129-135

[8] Dacombe R. Can we argue against it? Performance management and state funding of voluntary organizations in the UK. Public Money \& Management. 2011;31(3):159-166

[9] Greiling D. Balanced scorecard implementation in German non-profit organisations. International Journal of Productivity and Performance Management. 2010;59(6):534-554
[10] Hall M. Evaluation logics in the third sector. Voluntas: International Journal of Voluntary and Non-profit Organizations. 2014;25(2):307-336

[11] Reheul A-M, Tom C, Sandra V. Financial reporting lags in the nonprofit sector: An empirical analysis. Voluntas: International Journal of Voluntary and Nonprofit Organizations. 2014;25(2):352-377

[12] Schobel K, Cam S. Balanced scorecards in education. Measuring Business Excellence. 2012;16(3):17-28

[13] Viader AM, Espina MI. Are notfor-profits learning from for-profitorganizations? A look into governance. Corporate Governance. 2013;14(1):1-14

[14] Nicholls A. We Do Good Things, Don't-We? Blended Value Accounting in Social Entrepreneurship.

Accounting, Organizations and Society. 2009;34(6-7):755-769

[15] Huang HJ, Keith H. New Zealand funding organisations: how do they make decisions on allocating funds to not-for-profit organisations? Qualitative Research in Accounting \& Management 2011;8(4):425-449

[16] Rakar T, Vrbica S, Deželan T, Kolarič Z, Črnak-Meglič A, Nagode M, et al. Raziskava indeks civilne družbe: končno poročilo. Ljubljana: Inštitut Republike Slovenije za socialno varstvo in Pravno-informacijski center nevladnih organizacij; 2010

[17] Črnak-Meglič A, Vojnovič M. Vloga in pomen neprofitno-volonterskega sektorja v Sloveniji. Družboslovne Razprave. 1997;13(24-25):152-178

[18] Costa E, Ramus T, Andreaus M. Accountability as a managerial tool in non-profit organisations: Evidence from Italian CSVs. Voluntas: International 
Journal of Voluntary and Non-profit

Organisations. 2011;22(3):470-493

[19] Vrečko I. Strategija sistemskega razvoja nevladnih organizacij v Sloveniji za obdobje 2003-2008. Ljubljana: Slovensko združenje za Projektni Management; 2003

[20] De Cooman R, De Gieter S, Pepermans R, Jegers M. A cross-sector comparison of motivation-related concepts in for-profit and not-forprofit service organisations. Nonprofit and Voluntary Sector Quarterly. 2011;40(2):296-317

[21] Leete L. Wage equity and employee motivation in non-profit and forprofit organisations. Journal of Economic Behavior \& Organisation. 2000;43(4):423-446

[22] Kolarič Z. Različni znanstvenoteoretski pristopi k preučevanju neprofitnih organizacij. V Jadranje po nemirnih vodah menedžmenta nevladnih organizacij, ur. Dejan Jelovac. Ljubljana/Koper: Radio Študent/Visoka šola za Management; 2001. pp. 29-44

[23] Salamon LM, Anheier HK. The Emerging Non-profit Sector: An Overview. Manchester in New York: Manchester University Press; 1996

[24] Bruce I, Raymer A. Managing and Staffing Britain's Largest Charities. London: City University; 1992

[25] Douglas P. Governmental and Nonprofit Accounting. Theory and Practice. London: The Dryden; 1995

[26] Uradni list republike Slovenije. Strategija razvoja nevladnih organizacij in prostovoljstva. Ljubljana: Uradni list; 2018 
Section 2

\section{Theoretical Framework of Non-Profit Organisations}





\title{
Factors that Drive Volunteerism in Nonprofit Organizations: A Theoretical Framework
}

\author{
Mohammed Aboramadan
}

\begin{abstract}
This chapter aims at examining and reviewing the factors that drive volunteering in nonprofit organizations. The chapter follows a multidisciplinary approach in defining and examining the factors that drives individuals to volunteer in nonprofit organizations. The chapter provides a theoretical framework on how different factors are associated with volunteerism in nonprofit organizations. This chapter provides analysis of the volunteerism concept by looking at factors that drive volunteerism from diverse standpoints.
\end{abstract}

Keywords: drivers, nonprofits, volunteerism, framework

\section{Introduction}

The study of volunteerism has yielded different theoretical and conceptual models [1]. It spans across fundamentally different disciplines, serves organizations in a wide variety of industries, and changes from one country to another. In India, volunteering is strictly defined as "social work," while in Russia, no word is used to denote the concept [1]. Scholars who were admittedly daunted by the task of defining volunteerism, like Wilson [2] and Carson [3], noticed a pattern in literature. Definitions of volunteerism tend to state what "volunteerism is not" instead of defining what volunteerism is; "it is not paid labor, it is not slavery or forced labor, it is not kindship cate" [1].

This paper focuses on the interdisciplinary aspect of volunteerism. More specifically, we look at factors that drive volunteerism from multiple perspectives. Economic theory speculates that individuals are rational and self-interested. Hence, the notion of "unpaid labor" is absurd from an economic standpoint. Later, we look at how volunteerism is justified by economists. Sociologists, on the other hand, consider volunteerism to be a way of fostering social bonds, a sort of indulgence that serves the common good. While Economists assume rationality and sociologists look at social factors like solidary, psychologists inspect the "individual differences in psychological characteristics" [1]. In the last section, management factors are going to be discussed to answer further the question of why volunteers volunteer.

\subsection{Subjective dispositions}

Subjective disposition is a term that embeds many factors, namely, personality traits, motives, norms, and values. They can simply be described as the device or 
devices with which people interpret their external environment, hence the word "subjective" because different interpretations come from different people. The second key word "dispositions" refers to a person's tendency to react to a certain external stimulus. Subjective dispositions are inner factors that drive our choices in life.

\subsubsection{Empathy}

Many studies attempted to link personality traits with volunteerism. This causal relationship unveiled some interesting findings. Empathy is one personality trait that received a lot of interest in literature. It is generally seen as an important driver in prosocial behaviors. Smith [4] found that empathy is positively correlated with altruistic behaviors. Using General Social Survey Data, 15 prosocial behaviors were found to be correlated with an emphatic personality. Altruistic behaviors may encompass both formal and informal volunteering. Because the focus of this paper is on formal volunteering, we can refer to Bekkers [5] who, having used data from the family survey of the Dutch population, has deduced that empathy is one conclusive characteristic that is found in people who volunteer. Einolf [6] and Mitani [7]' results reconciled with Bekkers [5]. Empathy alone, however, was found to be insufficient to incite volunteerism. Wilhem and Bekkers [8] introduced a new variable called "principle of care" which describes the moral principle of helping others. Interestingly, emphatic concern was shadowed by the moral principle, indicating that the latter is much stronger than the mere emotion of empathy for others.

\subsubsection{Extraversion}

Having studied empathy, Bekkers [5] analyzed further personality traits. Looking at extraversion this time, he found that this variable is positively related with volunteer work. Not only that, when measured in terms of intensity of engagement, extraversion was concluded to be more typical of volunteers and less related to those who hold mere memberships. One year later, another study scrutinized the relationship between extraversion and volunteerism. As predicted, extraversion was very much attached to the personality of someone who volunteers than someone who does not [9]. However, the approach that was adopted in this study was somewhat more skeptical. Instead of studying the direct relationship between the two variables, structural equation modeling was used to divulge indirect factors that are more likely to relate extraversion to volunteerism. This mediational model encompassed three variables: clubs and organization, church attendance, and contact with friends. The major premise is that extroverts, who are more sociable and friendly, would have more presence in clubs and organizations, a higher turn up rate in churches, and a larger network of friends. These mediating factors were found to be determinative of volunteerism. In other words, when these factors were statistically controlled for, extraversion did not show a direct effect on volunteerism.

Consistently, Brown [10] and Carlo et al. [11] found that extraversion was strongly related to volunteerism. The second study, having also considered the mediation effect, found that there was no direct evidence of the interaction effect between extraversion and volunteerism. Rather, both extraversion and agreeableness applied a joint effect on prosocial value motivation. Therefore, prosocial value motivation is the real impetus that drives volunteerism. This entails that an extrovert person would not volunteer unless he or she already values helping others [11]. We can then draw the connection between Carlo's findings about prosocial value motivation and empathy that was previously discussed. 


\subsubsection{Agreeableness}

Carlo et al. [11] discovered that extraversion and agreeableness impacted prosocial value motivation conjointly. This brings us to our next variable: agreeableness. The same study uncovered that agreeableness had a significant direct impact on volunteerism [11]. One important distinguishing virtue of an agreeable person is compliance to others' requests. Volunteering is a field where compliance is needed. Hence, highly agreeable individuals would be more prone to volunteer than less agreeable individuals. A study utilizing the largest UK household survey (Understanding Society) assents to the before-mentioned positive relationship. Agreeableness was found to be positively associated with monetary donations and charitable causes [10]. On the other hand, an interesting conflicting outcome was pointed out by Bekkers [5]. This particular study endeavored to categorize volunteer work by distinguishing between political activism and civic engagement. Surprisingly, the study found that agreeableness was especially an attribute of political activists. This was sought to be peculiar because agreeableness was found to be positively correlated with empathy. In turn, empathy was proven to be positively related to civic engagement [5]. One major implication can be ratiocinated. That is, agreeableness is not typical of all volunteers.

\subsubsection{Social phobias}

Following commonsensical reasoning, if agreeable, extroverts are more prone to participate in volunteer work. It is only fair to assume that those who suffer from social phobias or anxieties would be less disposed to do so. Likewise, Handy and Cnaan [12] confirmed this hypothesis and many other deriving suppositions. From the outset, it is important to nuance between individuals with clinical social phobia and those with a moderate degree of social phobia. Clinical social phobia is more acute and characterized by a crushing fear of social interactions along with excessive self-consciousness in daily situations. The second case, on the other hand, is less severe. Individuals with mild levels of social phobia still manage to muddle through while being fearful of what might happen. Measuring both cases with Liebowitz Social Anxiety Scale, Handy and Cnaan [12] confirmed that people with higher social anxiety volunteer significantly less and are less susceptible to do so in the future. Additionally, the study investigated how people with different levels of social anxiety approached volunteering. As expected, people with higher levels of social phobia are more likely to volunteer upon request from a friend than on their own or through usual marketing tactics used by nonprofit organizations. Finally, the same study found that people with higher levels of volunteering prefer writing a check than actual volunteering. Donating money spares them the socially awkward confrontations and people's judgmental squints.

The last study presented us with ponderous insights about how nonprofit organizations should approach recruitment. Through personal asking, nonprofit organizations tend to face the volunteer recruitment fallacy, which holds that people who are presumed to be apt for volunteering do not actually volunteer. This leaves out a considerable population of shy and socially uncomfortable people who could potentially become productive volunteers. Besides social anxiety, depression was also found to be negatively related to volunteerism [13].

\subsubsection{Conscientiousness}

Another interesting line of investigation looked at conscientiousness and its relationship to volunteerism. Conscientiousness describes a large spectrum of 
constructs that revolve around self-control, hard work, rule abidance, and order in one's life [14]. Both Brown [10] and Donnelly et al. [15] concluded that conscientiousness is negatively related to volunteerism. Similarly, Bekkers [5] had found that volunteers were typically individuals with low level of conscientiousness. This is rather surprising because McCrae and John [16], in their initial description of the "Five Big Personality Traits," had described conscientiousness as being an impulsive, proactive behavior that stimulates growth through action.

\subsubsection{Openness to experience}

Another personality trait that was meticulously studied is openness to experience. Brown [10] found that, among all personality traits, openness to experience is the most substantial. He noted that one standard deviation increase is associated with a 6.4\%-point rise in the measured variable (volunteerism). In contrast, Bekkers [8] established that openness had no impact on the intention of donating money or allocating time for a given cause. Another study joins Brown's findings, but from a different perspective. Olympiad volunteers in Iran were studied as a sample with the intention to predict the personality traits that make volunteers satisfied from their experiences. Openness to experience, which encircles aspects of personal curiosity, art appreciation, and learned wisdom, was significantly linked to volunteers' satisfaction.

\subsubsection{Solidarity}

The discipline of sociology scrutinized several subjective dispositions. However, a number of questions regarding the impact of solidarity on volunteering behavior remain unanswered. Solidarity, as defined by Oxford Dictionary, is "unity or agreement of feeling or action, especially among individuals with a common interest; mutual support within a group" [17]. Although the variable was not directly inspected, some studies looked at similar patterns of behavior during community disasters. Adams and Boscarino [18] tried to bring forth a study where they explain what motivated people to volunteer during the World Trade Center Disaster (WTCD). Among other factors, volunteering was particularly associated with greater exposure to WTCD events and experiences of trauma from similar disastrous events [18]. This last study is reminiscent of Beyerlein and Sikkink [19] who looked at a pool of different independent variables, namely, proximity to the terrorist attack, personal connections to the victims, participation in religious congregations, patriotic responses, and so on. Interestingly, the two authors underline four variables that proved to be most relevant, that is, having previously known the victim, experiencing sorrow, feeling a personal responsibility to help the victims, and having volunteered prior to WTCD [19]. In retrospect, the feeling of solidarity figures in most of the variables mentioned, entailing that emotions are bolstered through community belongingness.

\subsubsection{Personal identity}

At the level of community, the feeling of solidarity has been proven to be a propelling force in the midst of chaos. From an individual perspective, we look at personal identity and its contribution to volunteerism. A growing body of literature has examined this relationship. However, before discussing the relationship between the two, we need to define the concept. According to Oyserman, personal identity provides answers to three pivotal questions: "Who am I?" "Where do I belong?" and "How do I fit?" [20]. The answers to these questions provide a biased 
theory of ourselves. Personal identity is sought to be tentative and always striving to become better [20]. Through volunteerism, the latter can fulfill a purpose. Grönlund [21] put forward an interesting interactive model where different interviewees developed their own self-image, thereby arriving at different types of identities. Volunteers were subsequently classified into five categories of identities, namely, influencer identity, helper identity, faith-based identity, community identity, and success identity. Interestingly, 4 interviewees out of 24 fell in the category of helper identity. Benevolence was sought to be their most salient value in life. Along with concerns for universalism and conservation, they endeavored to help others and thus volunteer.

By the same token, Matsuba et al. [22] used structural equation modeling to arrive to similar results. Studying a sample of American adults, they assessed the mediating effect of the helping identity on volunteering commitment. The construct of this variable focused on to extent to which individuals felt that they actually have control over the welfare of others, try to help the others, or see themselves doing so in the future. The study then finds that commitment to volunteering is strongly motivated by people who identify more with a helping identity. Volunteering can also be used to cloak problems of identity or lack of perceived identity [23]. For instance, people who have troubles succeeding in their professional career turn to volunteering as a way of adopting a different mission in life. Other people try to embark in volunteer work to fight stigmas [24].

Before discussing the theory of volunteerism in economics, a noteworthy theory should be mentioned. The "low-cost hypothesis" asserts that the effect of personality characteristics on a given prosocial behavior is reduced when costs associated with the behavior are higher. Bekkers et al. [5] is a study that tracks the mediating effect of this theory in the context of personality characteristics and volunteerism. According to the theory, individuals with high wages should consider volunteering a high-cost activity, while individuals with low wages should see it as a low-cost activity. Interestingly, agreeable and conscientious people were found to be "less likely to participate as they earned more" [5]. Having introduced the concept of opportunity cost and how it meddles between the discussed factors and volunteerism, we now move to the economic theory of volunteerism.

\subsubsection{Self-interest}

Economists joined this debate as well, contesting that people are motivated by self-interest when they decide to volunteer. Hayakawa [25] discusses the hidden facets of volunteer work. In his paper, he argues that volunteering today counts as work experience in CVs. It serves as a reference for the person's ability to indulge a different social environment while away from one's comfort zone. That said, Hayakawa is suspicious of the volunteer's intention in this case and makes it clear that volunteer work is done to cover up the fact that the person is unable to find other alternatives in the job market. In this sense, economic theory challenges the altruistic mindset in volunteering, with the chief assumption that volunteers would not volunteer unless they have interest in the activity. Gee's [26] demonstration of the latter assumption is fully endorsed by experimentation. In his paper, Gee compares between households who have children in multiple schools with households who got their children in the same school. With the aim to understand the real intention of parents' time contribution in schools, Gee found that having children in the same school elevated the willingness to volunteer by $13 \%$, hence concluding that parents are rather motivated by private interest of their own children rather than public interest for all students. Similarly, Maki and Synder [27] provide consistent results by showing that self-interest fuels the motivation to volunteer. 
This theory of selfishness in volunteering received much attention due to the fact that it is startlingly repulsive, yet only intrinsic. Self-interest is rather common, even in the supposedly "untainted" act of giving. In public duty, firefighters were more responsive to emergency calls if they purchased vanity plates. This is indicative of self-praise in doing social good. Firefighters who feel pride in helping others are more responsible in their jobs [28]. Within the same context of work duty, Bekkers [8] found that if the invitation to volunteer is solicited by a hierarchical superior, the chances that the person would decline the invitation go down. Volunteers are also motivated by networking. Prouteau and Wolf [29] found a positive correlation between volunteer work and number friends. Apart from the relational motive, Fiorillo [30] finds that monetary rewards influence intrinsic motivations and therefore alter the person's willingness to volunteer.

\subsubsection{Religion}

When investigating people' inner motives, it is unavoidable to tap into the subject of religion.

Using the main sample of the midlife development in the United States, Taniguchi [31] finds that religion is, in fact, a significant predictor of the propensity to volunteer. In a brief description of his findings, Taniguchi asserts that volunteers demonstrate more behavioral religiosity than non-volunteers. This is consistent with Bekkers's [5] positive correlation between church attendance and volunteer work, although it is noteworthy to mention that the Catholic European context is more active in volunteer work than the Orthodox one [32]. A common misconception is that religion-motivated volunteers are only more disposed to volunteer in religious institutions; Johnston [33] disputes against that by demonstrating that volunteerism is not only limited to religious institutions but rather expands into nonreligious institutions over time; Grönlund [34], with an ingenious attempt, scrutinizes different styles of religiousness. The first one having religion at the heart of volunteering and the second one associated with values and worldviews that an individual has, which in turn coincides with the religious views. The first type of religiousness is proven to be most associated with volunteerism [34].

The before-mentioned studies infer to religious affiliation. Inaba [35] approaches religion from a different aspect, the individual one. In his paper, Inaba argues that the source of volunteer work in the Japanese culture is inspired by "unconscious religiosity," which infers to the tendency to magnify individual work to a more grandiose purpose. Unconscious religiosity in the Japanese culture is similar to the Western concept of spirituality. Nevertheless, spirituality was found to be a significant negative predictor in the United States [36].

\subsection{Demographical characteristics}

In the broad and divisive debate of genetics versus environment, demographics are, for the most part, considered and given the attention they deserve. Needless to say that volunteering, like any other prosocial behavior, needs to be studied from that perspective as well. In this section of the literature review, we consider factors such as age, race, income, and education to further explain what drives volunteering.

\subsubsection{Gender}

Most of the literature above use gender as a control variable in their analysis. It is such an easy variable to include regardless of the research methodology the study is using. However, it is important to note that most of the studies that we are about to 
discuss have looked primarily at sex differences and how they impact volunteering, rather than just using gender as a mere control variable.

It seems that gender differences with regard to donating time and money vary from country to country. For the most part, women were more susceptible to volunteer than men. In the United States, for example, men do less volunteer work than women despite the fact they are at a slight disadvantage when it comes to income [37]. Einolf, therefore, suggests that prosocial motivation is more a characteristic of women than men. Other research support this finding [38]. The latest survey conducted by the Bureau of Labor Statistics in the United States confirmed this trend; $21.8 \%$ was the volunteer rate for men, while the rate for women was $27.8 \%$ [39]. In the United Kingdom, Brown [10] provides further evidence by stating that men donate $25 \%$ less than women. Surveys done in Australia consent to the findings to its fellow English-speaking countries, while Japan despite being distant in culture and language still shows more evidence for women volunteering than men [40]. In Canada, gender equality is reflected in men and women's tendencies to donate time or money, no significant difference between the two. Sweden lies at the other end of the spectrum with men being more prone to volunteer [40]. These cross-cultural differences could potentially indicate that the social aspect works as a stronger impetus to volunteering than the biological one.

Besides country considerations, gender differences vary across surveys. Most notably, lengthy surveys show little or no difference between men and women in volunteering [41, 42]. Hence, we can presume that the more a researcher digs by asking more questions, the slenderer the gap between men and women becomes.

Another noticeable difference lies in the nature of the volunteering activities that men or women tend to opt for. Men, for instance, are more likely to volunteer in sport and recreational activities, while women are interested in educational and human service organizations [40]. Nevertheless, looking at this study alone would rather provide a biased image. Organizations' standards in recruiting should also be taken into account. The domain of youth sport, which is essentially driven by volunteer workforce, is a good demonstration of double standards in recruitment. Men are mostly recruited for coaching positions, while women are recruited for supporting activities. Supporting activities involve back-office and secretarial work. As suggested by Messner and Bozada-Deas [43], gender roles in volunteer work are a mere reflection of gender roles in families. In this context, Wymer [44] validates some interesting hypothesis. He finds that females have a greater preference for nurturing roles in organizations such as helping infants and youth, while males are interested in risk-taking and dangerous volunteering experiences.

\subsubsection{Race}

Like gender, race is almost always controlled for when investigating other independent variables. There is little focus on the variable itself to predict prosocial behaviors. Johnson and Lee [45] find that Asians have less propensity to volunteer than Hispanics or Whites. Interestingly, when looking at the Black community, only educated Black individuals passed the significance test. Wilson and Hughes [46] maintain that Whites are more likely to volunteer than any other ethnic or racial groups, while Taniguchi [31] finds no significant effect of race in his model.

\subsubsection{Age}

There is a growing number of studies that looks at the impact of volunteerism on the well-being and mental illness of elderly individuals $[47,48]$. That is obviously beyond the scope of our study. We are rather interested in the antecedents 
of volunteerism. That said, age difference showed different motivational factors. For young individuals, it is the knowledge-seeking process that was more impelling [49]. This is only reasonable since the learning curve for young people is more curved upward than that of older people. Older people, on the other hand, were more driven by social motives [49]. In contrast, Dávilla and Díaz-Morales [50] found that younger people are more motivated by making new acquaintances than younger ones. However, the same study agreed with [49] with regard to career and knowledge concerns. While these two studies focused on age alone, most of the other studies that we discussed in previous sections controlled for that variable.

\subsubsection{Education}

There was a clear consensus in literature about how volunteerism is affected by educational attainment. That is, a positive causal relationship $[5,10,12,51]$. One particular study looked further at why education is such a strong predictor of volunteerism. Gesthuizen and Scheepers [52] tested nine ingeniously crafted hypotheses that consist of mediating factors that may interfere in the presumed relationship of volunteerism and education. We mention the validated ones, starting with the cognitive competence. The latter is enhanced and polished in academic formation and sought to induce volunteer work. Additionally, higher education was linked to higher-status jobs with broader horizons and therefore higher tendency to volunteer. Lastly, the strong positive relationship between volunteerism and education is explained by the fact that educated people have a more comprehensive understanding of world problems and more awareness leads to action.

\subsection{Management factors}

For a long time, nonprofit organizations were cautious with being associated with profit organizations. With the birth of hardcore capitalism, management practices were rather cruel and not considering of the workforce that was, for the most part, exploited. Today, however, management is no longer a "dirty word" [53].

Nonprofit organizations are today's essential. They are no longer the "trivial and inconsequential organizations" [54], and their influence in the political arena is far-stretched. "They have made a crucial difference in the way international justice is delivered" [55]. As their growth is going through the roof, their management approaches had to adapt and thrive. Nonprofit organizations are now faced with certain overwhelming expectations; this convergence toward professionalization is only natural to produce the high-quality services they are expected to deliver [56].

Because the trend of management in nonprofits is relatively new, the methodological design remains poor. Contrary to the conclusive results that we discussed in other factors, causal inferences cannot be drawn on this one [57]. The use of longitudinal design approaches raises a lot of questions about the legitimacy of the volunteerism research with regard to management practices.

Some studies, however, have taken the initiative to use more reliable methodologies. Tang et al. [58] used structural equation modeling to inspect the direct and indirect relationship between organizational support and volunteering benefits. The study subsequently concluded that organizational support linked was positively related to two variables of socioemotional benefits: perceived contribution and personal benefit. Surprisingly, an older study applied bivariate analysis and regression analysis to look into the impact of management practices, namely, recruiting, orientation, training, and supervision [59]. The positive relationship was found to be significant in this study as well, so was the case in [60-62], Stirling et al. [63] 
on the other hand, found that rigid management practices of keeping records, for example, are negatively associated with the retention of volunteers.

There is an abundant amount of other research that looks at similar concepts of organizations' incentivizing practices in nonprofits. Again, the methods used suffer from a plethora of pitfalls. They typically focus on specific cases, with no accurate sampling, which in turn limits the extent to which the results can be generalized [64].

Nesbit et al. [65] have developed a useful framework to assess volunteer involvement, with a special focus on how organizations affect volunteers' recruitment and retention. Organizations' characteristics were divided into "nature" and "nurture." The first type deals with characteristics that stem from the organization's nature such as mission, location, and sources of funds, while the second type includes leadership, culture, and staff receptivity to volunteers. Nesbit et al. [65] judge that organizations should rather focus on the "nurture" side of their volunteer program as it can more readily influence than characteristics found in the "nature" side; it is easier for an organization to change its style of leadership than to change its location.

Another exploratory study was done by Carvalho and Sampaio [66]. Using a multiple case study analysis of five Portuguese nonprofits, the study concludes that volunteering is "mostly an informal affair." Formal strategic planning is a scarce practice, and volunteer recruitment is conventionally transmitted through word of mouth. Even in the selection process, informality dominates as interviewers rarely have pre-defined criteria that need to be met. Training, although critical to the retention of volunteers, remains limited to one initial session only. Furthermore, Carvalho and Sampaio investigate other dimensions that are interrelated to the best practice in volunteer management. We can refer to the example of "centrality," defined in the paper as "the extent to which volunteer contribution is central to the organization's mission and is integrated into the overall running of the organization" [66]. Having contrasted two nonprofit organizations, one that is fully reliant on volunteers and another where paid employees ensure the central tasks, Carvalho and Sampaio assert that centrality to the mission and reliance on volunteers dictate the effort put into implementing good volunteer management practices.

Within the context of volunteer management practices, Ferreira et al. [54] devised a "life cycle of volunteers" with three critical phases: exploratory, developmental, and mature phase. The first stage is rather tentative; volunteers are yet to decide if they want to stay in the organization. In the second stage, volunteers are presumably more certain of their decision to stay in the organization and hence start to contribute. In the last stage, contribution is maximized and volunteers are now in a position to give to others. Ferreira et al. [54] advice that organizations need to approach these stages with effective management practices. In the first stage, where volunteers are indecisive, organizations ought to devise an ample plan to recruit them. In the second stage, training is, without a question, necessary as volunteers are still not equipped with the necessary tools to deal with some situations. Lastly, as volunteers mature and grow, rewarding is central to their retention as they are now a valuable asset to the organization.

\section{Conclusion}

This paper analyzed the interdisciplinary aspect of volunteerism. We looked at factors that drive volunteerism from an economic, sociological, psychological, and managerial standpoint. Literature considering the relationship between personality traits and volunteer work was meticulously studied. Most notably, empathy and extraversion proved to be highly correlated with volunteerism. Mediating factors were also unveiled, such as "principle of care" for the case of empathy. Agreeableness 


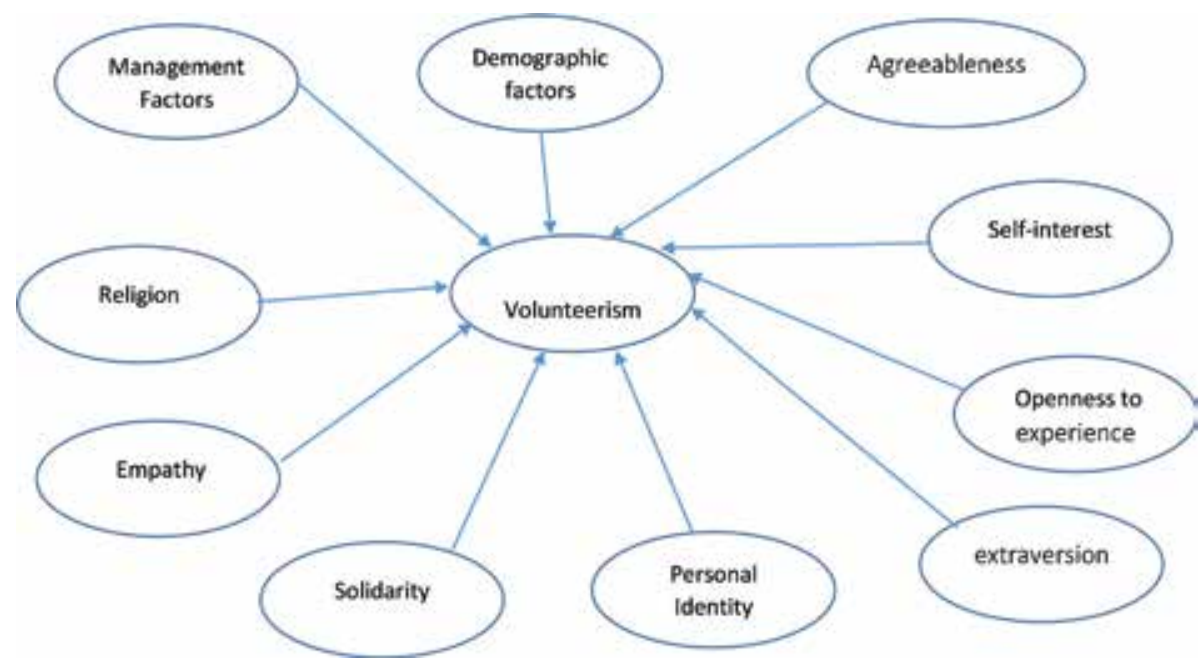

Figure 1.

Volunteerism drivers: A theoretical framework.

was linked to volunteer work but was not typical of all volunteers. On the other hand, conscientiousness was negatively related to volunteer work. Unsurprisingly, people with social phobias were less prone to volunteer. Other variables such as openness to experience, solidarity, and personal identity were given equal importance. We also looked at the economic theory of volunteerism that speculates that individuals are self-interested when they decide to volunteer. Moreover, we considered religion and its impact on individuals' willingness to volunteer. Then, we turned our focus to demographical factors such as gender, race, age, and education to provide a fuller and more solid answer to our research question. Lastly, we shifted from the perspective of the individual to that of the organization to see how management affect the willingness to volunteer. Based on the previous discussion, we suggest the following framework as presented in Figure 1 which can be a subject to future examination for validity purposes.

\section{Author details}

Mohammed Aboramadan

Department of Economics, Management and Statistics (DEMS), University of Milano-Bicocca, Milano, Italy

*Address all correspondence to: mohammed.aboramadan@unimib.it

\section{IntechOpen}

(C) 2019 The Author(s). Licensee IntechOpen. This chapter is distributed under the terms of the Creative Commons Attribution License (http://creativecommons.org/licenses/ by/3.0), which permits unrestricted use, distribution, and reproduction in any medium, provided the original work is properly cited. (cc) BY 


\section{References}

[1] Hustinx L, Cnaan RA, Handy F. Navigating theories of volunteering: A hybrid map for a complex phenomenon. Journal for the Theory of Social Behaviour. 2010;40(4):410-434

[2] Wilson J. Volunteering. Annual Review of Sociology. 2000;26:215-240

[3] Carson ED. On defining and measuring volunteering in the United States and abroad. Law and Contemporary Problems. 1999;62(4):67-72

[4] Smith TW. Altruism and Empathy in America: Trends and Correlates. National Opinion Research Center/ University of Chicago; 2006

[5] Bekkers R. Participation in voluntary associations: Relations with resources, personality, and political values. Political Psychology. 2005;26(3):439-454

[6] Einolf CJ. Empathic concern and prosocial behaviors: A test of experimental results using survey data. Social Science Research. 2008;37(4):1267-1279

[7] Mitani H. Influences of resources and subjective dispositions on formal and informal volunteering. Voluntas. 2014;25(4):1022-1040

[8] Bekkers R. Who gives what and when? A scenario study of intentions to give time and money. Social Science Research. 2010;39(3):369-381

[9] Okun MA, Pugliese J, Rook KS. Unpacking the relation between extraversion and volunteering in later life: The role of social capital. Personality and Individual Differences. 2007;42(8):1467-1477

[10] Brown S, Taylor K. Charitable Behaviour and the Big Five Personality
Traits: Evidence from UK Panel Data. Sheffield Economic Research Paper Series; 2015

[11] Carlo G, Okun MA, Knight GP, Guzman MK. The interplay of traits and motives on volunteering: Agreeableness, extraversion and prosocial value motivation. Personality and Individual Differences. 2005;38(6):1293-1305

[12] Handy F, Cnaan RA. The role of social anxiety in volunteering. Nonprofit Management \& Leadership. 2007;18(1):41-58

[13] Musick MA, Wilson J. Volunteering and depression: The role of psychological and social resources in different age groups. Social Science and Medicine. 2003;56(2):259-269

[14] Roberts BW, Lejuez C, Richards JM, Krueger RF. What Is Conscientiousness and How Can it Be Assessed? American Psychological Association; 2012

[15] Donnelly G, Iyer R, Howell RT. The big five personality traits, material values, and financial well-being of self-described money managers. Journal of Economic Psychology. 2012;33(6):1129-1142

[16] McCrae RR, Oliver JP. An Introduction to the Five-Factor Model and its applications. Journal of Personality. 1992;60(2):175-215

[17] Solidarity. Definition of Solidarity in English by Oxford Dictionaries. Oxford Dictionaries|English, Oxford Dictionaries. Available from: http:// en.oxforddictionaries.com/definition/ solidarity

[18] Adams RE, Boscarino JA. Volunteerism and well-being in the context of the world trade center terrorist attacks. International 
Journal of Emergency Mental Health. 2015;17(1):274-282

[19] Beyerlein K, Sikkink D. Sorrow and Solidarity: Why Americans Volunteered for 9/11 Relief Efforts. University of California Press; 2008

[20] Oyserman D. Self-concept and identity. In: Tesser A, Schwarz N, editors. The Blackwell Handbook of Social Psychology. Malden, MA: Blackwell; 2001. pp. 499-517

[21] Grönlund H. Identity and volunteering intertwined: Reflections on the values of young adults. Voluntas: International Journal of Voluntary and Nonprofit Organizations. 2011;22(4):852-874

[22] Matsuba K, Hart D, Atkins R. Psychological and social-structural influences on commitment to volunteering. Journal of Research in Personality. 2007;41(4):889-907

\section{[23] Baines S, Hardill I. 'At least I} can do something': The work of volunteering in a community beset by worklessness. Social Policy and Society. 2008;7(3):307-317

[24] Fuller S, Kershaw P, Pulkingham J. Constructing 'active citizenship': Single mothers, welfare, and the logics of voluntarism. Citizenship Studies. 2008;12(2):157-176

[25] Hayakawa T. Selfish giving? Volunteering motivations and the morality of giving. Traditiones. 2014;43(3):16-32

[26] Gee LK. The nature of giving time to your child's school. Nonprofit and Voluntary Sector Quarterly. 2011;40(3):552-565

[27] Maki A. Investigating similarities and differences between volunteer behaviors: Development of a volunteer interest typology. Nonprofit and Voluntary Sector Quarterly. 2015;46(1):5-28

[28] Carpenter J, Myers CK. Why volunteer? Evidence on the role of altruism, image, and incentives. Journal of Public Economics. 2010;94(11-12):911-920

[29] Prouteau L, Wolff F. On the relational motive for volunteer work. Journal of Economic Psychology. 2008;29(3):314-335

[30] Fiorillo D. Do monetary rewards crowd out the intrinsic motivation of volunteers? Some empirical evidence for italian volunteers. Annals of Public and Cooperative Economics. 2011;82(2):139-165

[31] Taniguchi H, Thomas LD. The influences of religious attitudes on volunteering. Voluntas. 2011;22(2):335-355

[32] Montes AA, Valencia PT, Rodríguez VF, Hager MA. Religion and volunteering over the adult life course. Journal for the Scientific Study of Religion. 2018;6(1):82-111

[33] Johnston JB. Religion and volunteering over the adult life course. Journal for the Scientific Study of Religion. 2013;52(4):733-752

[34] Grönlund H. Religiousness and volunteering: Searching for connections In late modernity. Nordic Journal of Religion and Society. 2012;25(1):47-66

[35] Inaba K. Unconscious religiosity and social capital. Religion and Social Contribution. 2011;1(1):3-26

[36] Okun MA, O’Rourke HP, Keller B, Johnson KA, Enders C. Value-expressive volunteer motivation and volunteering by older adults: Relationships with religiosity and spirituality. Journal of Gerontology. 2015;70(6):860-870 
[37] Einolf CJ. Gender differences in the correlates of volunteering and charitable giving. Nonprofit and Voluntary Sector Quarterly. 2011;40(6):1092-1112

[38] Themudo NS. Gender and the nonprofit sector. Nonprofit and Voluntary Sector Quarterly. 2009;38(4):663-683

[39] Bureau of Labor Statics.

Volunteering in the United States; 2015

[40] Musick MA, Wilson J. Volunteers : A Social Profile. Indiana. Bloomington: Indiana University Press; 2008

[41] Bekkers R, Wiepking P. To give or not to give, that is the question: How methodology is destiny in Dutch giving data. Nonprofit and Voluntary Sector Quarterly. 2006;35(3):533-540

[42] Rooney PM, Mesch DJ, Chin W, Steinberg KS. The effects of race, gender, and survey methodologies on giving in the US. Economics Letters. 2005;86(2):173-180

[43] Messner MA, Bozada-Deas S. Separating the men from the moms. Gender \& Society. 2009;23(1):49-71

[44] Wymer W. Developing more effective social marketing strategies. Journal of Social Marketing. 2011;1(1):17-31

[45] Johnso K, Lee HS. Factors associated with volunteering among racial/ethnic groups: Findings from the California health interview survey. Research on Aging. 2015;39(5):575-596

[46] Wilson O, Hughes O. Urban green space policy and discourse in England under new labour from 1997 to 2010. Planning Practice and Research. 2011;26 (2):207-228

[47] Hansen T, Aartsen M, Slagsvold B, Deindl C. Dynamics of volunteering and life satisfaction in midlife and old age: findings from 12 European Countries. Innovation in Aging. 2018;2(1):657

[48] Von Bonsdorff MB, Rantanen T. Benefits of formal voluntary work among older people. A review. Aging Clinical and Experimental Research. 2011;23(3):162-169

[49] Yussof R, Wan N, Mohamed W. Age and motives for volunteering: From Socioemotional selectivity theory perspective. In: Proceedings of the Academic Symposium of Social Science. 2015

[50] Dávila MC, Díaz-Morales

JF. Age and motives for volunteering: Further evidence. Europe's Journal of Psychology. 2009;5(2):82-95

[51] Balduck A, Rossem AV, Buelens M. Identifying competencies of volunteer board members of community sports clubs. Nonprofit and Voluntary Sector Quarterly. 2010;39(2):213-235

[52] Gesthuizen M, Scheepers P. Educational differences in volunteering in cross-National Perspective: Individual and contextual explanations. Nonprofit and Voluntary Sector Quarterly. 2012;41(1):58-81

[53] Cunningham I. Human resource management in the voluntary sector: Challenges and opportunities. Public Money \& Management. 1999;19(2):19-25

[54] Ferreira M, Proença JF, Proença T. Motivations and Management Factors of Volunteer Work In Nonprofit Organisations: A Literature Review. University of Porto; 2009

[55] Dar F. Emerging role of NGOs in the world's socio-political affairs. International Journal of Peace and Development studies. 2014;6(1):1-19

[56] Chater D. Coming in from the Cold? The Impact of the Contract Culture 
on Voluntary Sector Homelessness Agencies in England. Voluntary Sector Working Paper, 10. 2008. pp. 1-37

[57] Mason DP. Putting charity to the test: A case for field experiments on giving time and money in the nonprofit sector. Nonprofit and Voluntary Sector Quarterly. 2013;42(1):193-202

[58] Tang F, Choi E, Morrow-Howell N. Organizational support and volunteering benefits for older adults. The Gerontologist. 2010;50(5):603-612

[59] Cnaan RA, Cascio TA. Performance and commitment: Issues in management of volunteers in human service organizations. Journal of Social Service Research. 1998;24(3):1-37

[60] Cuskelly G, Taylor T, Hoye R, Darcy S. Volunteer management practices and volunteer retention: A human resource management approach. Sport Management Review. 2006;9(2):141-163

[61] Resnick B, Klinedinst J, Dorsey S, Holtzman L, Abuelhiga LS. Volunteer behavior and factors that influence volunteering among residents in continuing care retirement communities. Journal of Housing for the Elderly. 2013;27(1-2):161-176

[62] Hager MA, Brudney JL. Problems recruiting volunteers: Nature versus nurture. Nonprofit Management and Leadership. 2011;22(3):137-157

[63] Stirling C, Kilpatrick S, Orpin P. A psychological contract perspective to the link between non-profit organizations' management practices and volunteer sustainability. Human Resource Development International. 2011;14(3):321-336

[64] Studer S, Schnurbein GV. Organizational factors affecting volunteers: A literature review on volunteer coordination. VOLUNTAS:
International Journal of Voluntary and Nonprofit Organizations. 2013;24(2):403-440

[65] Nesbit R, Christensen RK. The Limits and Possibilities of Volunteering: A Framework for Explaining the Scope of Volunteer Involvement in Public and Nonprofit Organizations. Public Administration Review; 2017;78(4):502-513

[66] Carvalho A, Sampaio M. Volunteer management beyond prescribed best practice: A case study of Portuguese non-profits. Personnel Review. 2017;46(2):410-428 
Section 3

Governments and Non-Profit Organisations 



\title{
On Relations between Government and Non-profits: The Case of Slovakia
}

\author{
Mária Murray Svidroňová
}

\begin{abstract}
In this chapter, we look at non-profits and civil society as a transit zone for solidarity acts, social innovations and initiatives to influence social policy by means of co-creation and collaboration with government (public sector organisations). The aim is to present collaboration practices between public sector organisations, non-governmental organisation, social economy organisations and citizens, known as co-creation, with a focus on drivers and barriers of this collaboration in Slovakia. The chapter focuses on channelling solidarity produced by non-profits into social policy through co-creation. Introducing the solidarity economy approach allows us to evaluate the relationships between the government sector and non-profit organisations from a broader societal perspective including both economic and democratic dimensions.
\end{abstract}

Keywords: public sector, non-profits, NGOs, civil society, social economy, solidarity economy

\section{Introduction}

This chapter investigates how far the third sector and social economy act as a transit zone for solidarity acts, social innovations and initiatives to impact social policy. It focuses on forms of co-creation of welfare services, on gaining voice in public discourse to influence public policy practices and on the barriers and drivers for channelling grassroots initiatives and ideas into political practice.

This part of the chapter provides an overview of the key concepts and literature on the third sector, social innovation and co-creation, outlining the development of the research field by mirroring on the sphere of citizen action-social movements, civil society, third sector and social economy organisations-situated between the classical spheres of market and state.

Let us start with a question: Which came first, the social economy or the third sector? Proponents of the social economy argue that the terms 'civil society' and 'third sector' are just names for the social economy in the countries of Eastern Europe, where the civil society developed after the fall of communism. Proponents of the third sector argue the opposite that the social economy only appropriates what the third sector built a long time ago: active citizenship reflected into founding civic associations. 
Cohen [1] stated that after the demise of state socialism in Eastern Europe, in which citizen movements played an important role, the concept of civil society became increasingly related to changes in institutional politics to address a perceived crisis of legitimacy of representative democracy and failing financial institutions. Apparently, neither the centralised state nor the magic of the marketplace can offer effective, liberal and democratic solutions to the problems of 'post-industrial' civil societies in the context of globalisation, introducing an economic dimension to civil society that finds expression in the emerging social economy.

Defourny [2] offers a distinction of three types of established social economy organisations: cooperative-style enterprises that go back to the mid-nineteenth century (working in agriculture, saving and credit, insurance and housing); mutual, based in the third sector or as part of the welfare state, working at community level; and advocacy associations offering services to members and society. While some of the old cooperatives, that is, in agriculture, have become more like conventional private businesses [3], the new social economy comprises 'new service cooperatives, voluntary organisations and social enterprises' [4], such as the British Community Interest Companies [5], social cooperatives in Italy [6], entrepreneurial spin-offs of traditional third sector organisations producing social services or concerned and responsible groups of citizens who want to make a difference [7].

The development of the social economy is unquestionably influenced by the development of the third sector that focuses on the provision of public services, including social services. Non-governmental organisations (NGOs) earned their position in the economy of every developed country as social innovators and important actors in the social economy. Many social economy subjects take the legal form of civic associations or public benefit organisations. Third sector organisations can be seen in a certain light as social economy organisations, especially when taking into account, all the similarities between these two types of organisations summarised in Table 1.

To answer the question from the beginning, based on the above mentioned, we believe that third sector came first. The shift of third sector organisations towards the use of market resources, first observed in Europe during the 1990s as a means to respond to social deficits not addressed by social services and growing funding constraints, led to a re-orientation in third sector research towards notions of social enterprise and social entrepreneurship [7].

In sum, conceptualisations of the third sector vary across Europe and are connected to deeper cultural traditions. They focus on different features such as charitable purpose, non-profit distribution, expressions of social solidarity, or civic values such as public participation. Nevertheless, all of these potential manifestations of the third sector share certain common attributes: they are all institutionally separate from government, they share a high degree of self-governance, and they have a social mission that is pursued on a voluntary basis. Based on this common core, Salamon and Sokolowski [9] recently proposed a definition of the third sector that includes both non-profit institutions and some social economy organisations that: (i) pursue a legally binding social mission; (ii) operate under an 'asset lock'; (iii) are prohibited from distributing more than $50 \%$ of profits; and (iv) include at least $30 \%$ of individuals with specified special needs among its employees or beneficiaries. The last two requirements have been criticised as too high and difficult to achieve even for work integration social enterprises who employ people otherwise excluded from the labour market. Appreciating that the combined public purpose dimension and limited profit distribution constraint is a way to broaden a third sector conceptualisation strictly based on non-profit institutions, Defourny and Nyssens [10] argue that it still needs further research to better understand the great diversity within the cooperative and social enterprise. 
On Relations between Government and Non-profits: The Case of Slovakia

DOI: http://dx.doi.org/10.5772/intechopen.89482

\begin{tabular}{|c|c|c|}
\hline Sector characteristic & $\begin{array}{l}\text { Social economy/social } \\
\text { enterprises (SEs) }\end{array}$ & Third sector/NGOs \\
\hline Goal & $\begin{array}{l}\text { Fulfilment of social mission-To } \\
\text { serve a local community or } \\
\text { specific groups of citizens }\end{array}$ & $\begin{array}{l}\text { Fulfilment of organisation's } \\
\text { mission-To provide social } \\
\text { benefits }\end{array}$ \\
\hline Institutions & $\begin{array}{l}\text { A wide variety of organisational } \\
\text { forms, including public benefit } \\
\text { organisations, cooperative } \\
\text { organisations, joint stock } \\
\text { companies and limited liability } \\
\text { companies }\end{array}$ & $\begin{array}{l}\text { Formalised and institutionalised } \\
\text { structures, legal form given by } \\
\text { law, usually associations and } \\
\text { public benefit organisations, but } \\
\text { also foundations and non-profit } \\
\text { funds }\end{array}$ \\
\hline Autonomy & $\begin{array}{l}\text { Social enterprises are usually } \\
\text { created and managed by a group } \\
\text { of people on the basis of an } \\
\text { autonomous business plan }\end{array}$ & $\begin{array}{l}\text { NGOs are not part of the } \\
\text { public administration: they are } \\
\text { institutionally separated from } \\
\text { the state and have political } \\
\text { independence }\end{array}$ \\
\hline Non-distribution constraint & $\begin{array}{l}\text { Limited distribution of profit } \\
\text { to shareholders or employees } \\
\text { and the obligation to reinvest } \\
\text { the profit (or a substantial } \\
\text { part of the profit) to the social } \\
\text { objectives of the enterprise }\end{array}$ & $\begin{array}{l}\text { NGOs are not founded to generate } \\
\text { profit to be shared among the } \\
\text { owners or managers, and any } \\
\text { profits are fully returned to } \\
\text { the organisation and used in } \\
\text { accordance with its statutes }\end{array}$ \\
\hline Voluntarism & $\begin{array}{l}\text { A combination of volunteers } \\
\text { and paid staff; a minimum level } \\
\text { of paid work }\end{array}$ & $\begin{array}{l}\text { Voluntary participation in } \\
\text { activities of the NGOs; a high } \\
\text { proportion of volunteering }\end{array}$ \\
\hline Civic initiatives & $\begin{array}{l}\text { Typically, the result of collective } \\
\text { dynamics involving citizens or } \\
\text { members of groups sharing a } \\
\text { common goal or community } \\
\text { need }\end{array}$ & $\begin{array}{l}\text { Established by citizens for the } \\
\text { purpose of achieving a mutual or } \\
\text { generally useful purpose/benefit }\end{array}$ \\
\hline $\begin{array}{l}\text { Entrepreneurial/business } \\
\text { activity }\end{array}$ & $\begin{array}{l}\text { Business is a main activity; } \\
\text { goods and services are } \\
\text { produced, i.e. they enter } \\
\text { the market and offer their } \\
\text { production for sale }\end{array}$ & $\begin{array}{l}\text { Funded under redistribution } \\
\text { mechanisms; entrepreneurship is } \\
\text { seen as a side activity }\end{array}$ \\
\hline Funding & $\begin{array}{l}\text { Financial sustainability depends } \\
\text { on the performance of members } \\
\text { and staff and their efforts to } \\
\text { ensure adequate resources; } \\
\text { activities are also funded } \\
\text { through financial support } \\
\text { mechanisms from public and } \\
\text { private sources; multisource } \\
\text { funding is used }\end{array}$ & $\begin{array}{l}\text { Multisource funding is a principle; } \\
\text { this may be a combination of } \\
\text { public (government) sources, } \\
\text { private and individual sources, } \\
\text { grants, membership fees, income } \\
\text { from self-financing and business } \\
\text { activities }\end{array}$ \\
\hline Management & $\begin{array}{l}\text { Participatory governance, } \\
\text { decision-making involves all } \\
\text { stakeholders }\end{array}$ & $\begin{array}{l}\text { Self-governance; they manage } \\
\text { themselves through established } \\
\text { organisational structures; the } \\
\text { main body is usually a general } \\
\text { assembly }\end{array}$ \\
\hline
\end{tabular}

Source: Vaceková and Murray Svidroňová [8].

Table 1.

Comparison of social economy and third sector characteristics.

The third and social economy sectors are under stress. Scholars in the field argue, reflected in policy changes, that we have reached a juncture, where societies have to choose between a greater role for civil society, the third sector and the social economy 
as providers of welfare, on the one hand, or unregulated privatisation, on the other [11]. In addition to that, Hulgård [12] detects a trend that steadily changed civil society from being a category related to political philosophy, the enhancement of citizenship and the possibility of democratic governance to a question of training business leaders to better identify and serve the markets at the bottom of the pyramid.

If political institutions are supportive of civil society, non-profit non-governmental organisations show the ability of a society to organise itself. Scholars agree that a lively non-profit non-governmental landscape contributes to institutional diversity and can have a positive impact on innovations in civil society [13]. Many European governments are seeking new ways to involve citizens and the third sector in the provision and governance of publicly financed welfare services [11].

Despite social enterprise and social entrepreneurship being a young field of academic research, which started in the 1990s with the observation of work integration enterprises, it has already produced a multitude of conceptual, analytical and comparative work [11, 14-16]. Scholars in economics and business studies have been very effective at explaining the economic rationale behind the emergence of social enterprises $[17,18]$ and the characteristics, dynamics and strategies deployed by these organisations in an uncertain and resource-limited environment $[19,20]$. The 2008 financial and economic crisis and the turn towards austerity triggered a more financial approach, illustrated by the vast body of literature currently under development on 'social' and 'impact investment' [21].

\section{Moving towards a solidarity economy}

Researchers on social and solidarity economy agree that the market-state dualism (state vs. market as expressed in liberalism vs. state socialism) inherited from the twentieth century is outdated [22]. Organisations in a solidarity economy are envisaged from the outset as voluntarily engaged in forms of public action for the common good. The participatory governance dimension takes centre stage in a conceptualisation of the social economy that highlights a more organic notion of solidarity rooted in pluralist civil society and social movements, coupling it with economic understandings of citizen initiatives and third sector.

The public space as a sphere of democracy expressed in citizen and civil society action is combined with a pluralist notion of economy: market economy, nonmarket economy and non-monetary economy, the latter two describing:

1. redistribution of produced goods and services by foundations or public institutions as part of the welfare state, providing citizens with individual rights, subject to democratic control;

2. redistribution of goods based on reciprocity, turning vulnerable people into co-producers and co-owners [22, 23].

Such a characterisation of solidarity economy is theoretically influenced by Karl Polanyi and his notion of reciprocity inherent to the market, and empirically inspired by the emancipatory movements in Latin America [24].

Polanyi [25] acknowledged the profit motive of capitalist economy but referred to a 'fictitious commodification' of labour, social and private spheres by drawing attention to economic practices, such as redistribution, reciprocity and household administration, safeguarded by a double movement of political elites and commercial interests on the one hand, and cross-class social movements leading to understand that it needs regulation in order to save society on the other. Thus, the 
market becomes culturally and politically embedded, rather than autonomous and dominating political and private spheres, manifesting itself in the structure of government redistribution, but also in social rights and legislative and regulatory mechanisms, such as collective bargaining [26].

Nowadays, Fraser [27] argues that we must add a critique of domination to Polanyi's structural critique of fictitious commodification, and since today, it also affects the sphere of social reproduction, site of giving birth to and raising children, caring for family members and maintaining households, which is increasingly outsourced to low-paid help. She proposes to think instead of a triple movement that includes civil society, by bringing in the post-war emancipatory movements that rally around status such as gender, ethnicity, sexuality, religion or nationality that exposed the suppressive factors of national welfare and social protection and demand to find a new synthesis between social protection and marketisation. This infrastructure of a solidarity economy is aware that a wage could serve as a resource against domination premised on status ... they claimed the freedom of contract not as an end in itself, but rather as a means to emancipation, converting the social dimension into economic leverage or specific productive strength.

While Fraser [27] herself points out the possible detrimental effects of emancipation on the fabric of existing solidarities as it may open a path for marketisation that can erode the ethical basis of social protection, she also states that considering the scale at which crisis is experienced today, the welfare state alone cannot protect against the decommodifiying side-effects of competition, international markets and currencies without political and social integration. Hence, solidarity economy can be regarded as complementary of third sector and social economy, existing next to the for-profit market.

Empirical evidence from Latin America shows that apart from rare exceptions, solidarity enterprises do not replace existing forms of popular economy. Their main purpose is to reorganise the productive, material and human factors of the popular economy through progressive changes [24]. This requires certain structural conditions, namely the social and political recognition of the relevance of claims, a favourable regime and favourable legislation $[11,15]$. Indeed, the concept has gained the attention of policy makers in a number of countries and at EU level, albeit still lacking supportive policies at national levels [28].

Solidarity economy identifies scope for the de-commodification of individuals due to its civil society base and focus on collective governance, self-organised production and democratic reciprocity that turns vulnerable people into co-producers and co-owners [23], rather than recipients of philanthropic expressions of solidarity that substitutes for the vocabulary of equality and rights that of public benevolence [24]. Solidarity in these ventures is evident in their members' involvement in day-to-day management and the adoption of equality principles, by placing new actors into work, recognition struggles or discourse of a meaningful life. Similar to the notion of associations as schools for democracy, solidarity encourages broader reciprocity practices, where practical experience in managing the common good lends new value to the notions of justice and public interest.

The notion of democratic solidarity dominant in solidarity economy could be considered an additional conceptual dimension in relation to 'successful acts of solidarity'. Defining solidarity as a morally motivated action arising from the feeling of an agent or a group recognising another individual or person's grief or discomfort, an actor is prone to be solidary with a certain group based on how 'deserving' the actor finds the other person or group in relation to 'control or responsibility, need, identity, attitude (e.g. gratefulness) and reciprocity' that is linked to notions of membership and inclusion that one can identify with [29]. It is generally of an altruistic or philanthropic nature. Laville [23] on the other hand criticises 
philanthropic solidarity for bringing a mechanism of social hierarchy and support for the inequality that is built into the social fabric of the community.

The concept of democratic solidarity is built on redistribution to reinforce social cohesion and to redress inequality and an egalitarian understanding of reciprocity as a way to enhance voluntary social relations between free and equal citizens. This relation between redistribution and reciprocity is the foundation of democratic solidarity in which it is not a question of replacing the state with civil society but rather one of combining redistributive solidarity with a more reciprocal version of the latter in order to rebuild society's capacity for self-organisation [23]. Solidarity is produced in such a way that the recipient can become the giver, drawing on Mauss' theory of the gift [30] and focus on social expectations that appear when one person gives and another receives a gift, creating an expectation for the receiver to return a favour. Democratic solidarity aims to allow for the recipient to reciprocate, as to avoid the permanent position of inferiority [23].

Situated within third sector and social and solidarity economy research (but not exclusive to them) are the concepts of social innovation and co-creation of welfare services, moving to the core of our objective to understand the channelling of solidarity practice into social policy in the case of the Slovak Republic.

By co-creation we understand such provision of public services in which citizens are actively involved, the following three types of co-creation can be distinguished [31]: (1) in which citizens act as initiator (co-initiate); (2) in which citizens are invited to co-design (co-design); and (3) in which citizens are 'just' invited to implement public services (instead of public organisations) (co-implement).

Co-creation is a narrowly defined aspect of civil society and third sector activity. Hence, the trend of co-production of social services is less tainted by suspicions that ultimately more scope for citizen participation will effectively make way for a discourse of civic duties linked to being a community member that allows states to withdraw from public welfare, as is the criticism in social economy discourse [32]. Co-creation is more centred on empowerment through participation in a civil society tradition, located in a new public governance approach that is a response to New Public Management of the 1980s and 1990s, where public services were viewed as manufacturing rather than service provision, leading to privatisation, contracting out, systematic performance measurement and benchmarking, turning citizens into consumers rather than users of a service [33] failing to grasp the complexity of today's plural (multiple interdependent actors contribute to the delivery of public services) and pluralist states (multiple processes inform policy) [34].

\section{Collaboration practices}

To map the relations between government and non-profits in Slovakia, we used a focus group. This method represents a homogeneous composed group of 6-12 participants discussing in a well-prepared way their ideas, motives and interests about a clearly defined issue chaired by a discussion leader. To guide the discussion, a list with topics was used and the discussion was recorded. Official invitations to participate in the focus group were addressed to 10 people. These included representatives of nonprofits, public institutions and municipalities that are promoting solidarity actions, as well as academic experts on solidarity issues. Eight out of 10 people agreed to participate in the focus group (we respect those, who wished to be fully anonymous):

- A university employee-academic expert, female;

- Municipality of Banska Bystrica representative, female; 
- NGO 1 from Banska Bystrica-director, female;

- NGO 2 from Banska Bystrica-leader, male (The Civic Association for the Amphitheater);

- NGO 3 from Bratislava-project manager, female;

- NGO 4 from Zvolen—project manager, female (EPIC n.o.);

- Public institution employee, male;

- Participant of community education programme, male.

The selection of case studies followed these criteria:

- there are cases with public organisations, NGOs and citizens involved;

- the selected cases represent four different policy areas (i.e. abandoned public properties, employment, health and education);

- at least, half of the case studies conducted are oriented to the fight against poverty and social exclusion;

- contain an element of third sector collaboration with public institutions, that is, a participant representing a social initiative producing a social service and their contact person at the municipality as the funding partner/co-creator.

The selection of cases was based on the focus group experts' judgment, which might be biased, however, the finding allows us to identify characteristics on government-non-profits relations in Slovakia. The analysed cases of collaboration practices are summarised in Table 2.

Since we were interested in collaboration between the non-profits or social economy organisations collaborating with public institutions (i.e. participants producing a social service possibly within the areas of education, health, abandoned properties, employment and their contact person at the municipality as the funding partner/co-producer), we asked about the nature of the collaboration and why this collaboration started to achieve what goal.

The collaboration includes specific short-term projects (education and employment), whereas in the field of health and abandoned properties, there is a longterm collaboration. The values sought from the public institutions' side were mostly about increasing efficiency, providing public services in a better way or using the option that the public service is provided by the NGO (using the activity and willingness of the NGO as an alternative public service provider).

From the NPOs' point of view, the key values guiding their choices for collaboration were: intersectoral cooperation and synergy, open communication and fulfilling the mission of the organisation.

\subsection{Distribution of roles}

In this part, we asked questions such as: How would you describe the nature of your relationship and the distribution of roles (non-profit partner as initiator, co-designer, co-implementer)? Has there been a change in the nature of your relationship over time (i.e. from hierarchy to equality/reciprocity, or perhaps even the other way around)? 


\begin{tabular}{|c|c|c|}
\hline Field & Programme and partners & Overview \\
\hline Employment & $\begin{array}{l}\text { Youth Guarantee on the local } \\
\text { level } \\
\text { Partners: } \\
\text { - EPIC, non-profit organisation } \\
\text { - Municipality of Zvolen } \\
\text { - Municipality of Turku } \\
\text { - Network of local NGOs } \\
\text { - Local secondary schools and } \\
\text { university } \\
\text { - Youth }\end{array}$ & $\begin{array}{l}\text { The aim is to pilot test the good practice of Youth } \\
\text { Guarantee (YG) approach from Finland in the } \\
\text { environment of one Slovak municipality. The } \\
\text { realisation of this objective shall be the starting } \\
\text { point for the possible revision of the YG applications } \\
\text { in Slovakia towards the local level. By creating } \\
\text { a working group from one region, the EPIC } \\
\text { organisation has empowered them to create a series } \\
\text { of events for NEET (Not in Education, Employment } \\
\text { or Training) and several initiatives have started to } \\
\text { help NEET at the local level. }\end{array}$ \\
\hline Education & $\begin{array}{l}\text { School of family finance } \\
\text { programme } \\
\text { Partners: } \\
\text { - Local NGOs } \\
\text { - Universities } \\
\text { - Citizens from various } \\
\text { communities } \\
\text { - the Ministry of Education, } \\
\text { Science, Research and Sport of } \\
\text { the Slovak Republic }\end{array}$ & $\begin{array}{l}\text { The School of Family Finance (SFF) is aimed at } \\
\text { increasing financial literacy and thus improving } \\
\text { the lives of the participants. After completion of } \\
\text { the course, the participants are more aware of } \\
\text { their personal responsibility for their financial } \\
\text { behaviour. Socially disadvantaged citizens, senior } \\
\text { citizens, children from orphanages, clients of } \\
\text { crisis centres and other groups of citizens have the } \\
\text { opportunity to realise how their decisions affect } \\
\text { their financial situation. The topics of the seminars } \\
\text { are chosen based on the needs and interests of the } \\
\text { participants, including topics such as looking for } \\
\text { a job, labour issues, taxes, personal and family } \\
\text { budget, loans, insurance, consumer protection, } \\
\text { basics of investment, etc. }\end{array}$ \\
\hline Health & $\begin{array}{l}\text { Non-governmental organisation } \\
\text { helping people with autism - } \\
\text { initiative in cooperation with the } \\
\text { municipality of Banska Bystrica } \\
\text { Partners: } \\
\text { - Local NGO } \\
\text { - Municipality of Banska } \\
\text { Bystrica } \\
\text { - Disabled citizens and their } \\
\text { families }\end{array}$ & $\begin{array}{l}\text { The nature of cooperation is a partnership based on } \\
\text { the principle of subsidiarity. A local NGO is one of } \\
\text { the key actors in the Community Social Services Plan } \\
\text { process in the town for the target group of a person } \\
\text { with disabilities as well as for the target group of } \\
\text { families with children with disabilities. One result is, } \\
\text { for example, education for parents who are at home } \\
\text { long-term caring for children. This enables parents } \\
\text { to once again socialise during the education courses } \\
\text { thereby helping to solve the problem of unproductive } \\
\text { parents as well as autistic community problems. }\end{array}$ \\
\hline $\begin{array}{l}\text { Abandoned } \\
\text { properties }\end{array}$ & $\begin{array}{l}\text { The civic association for the } \\
\text { amphitheatre } \\
\text { Partners: } \\
\text { - Local NGO } \\
\text { - Municipality of Banska } \\
\text { Bystrica } \\
\text { - Citizens } \\
\text { - Company }\end{array}$ & $\begin{array}{l}\text { Public Amphitheatre was once a vibrant cultural } \\
\text { place for outdoor cinema and special events. } \\
\text { With the arrival of a multiscreen cinema in the } \\
\text { local shopping mall, it was abandoned. After } \\
\text { the municipality put it on the list of non-usable } \\
\text { property, which was only a step away from being } \\
\text { demolished, a group of young enthusiasts formed } \\
\text { an NGO to save the Amphitheatre. They signed a } \\
\text { co-operation memorandum with the municipality, } \\
\text { and in cooperation with a private company, they } \\
\text { revitalised the Amphitheatre. The main activity of } \\
\text { the NGO remains the support of the Amphitheatre } \\
\text { in the form of organising a summer movie theatre } \\
\text { or other events with the aim of helping the } \\
\text { Amphitheatre to become a vibrant cultural and } \\
\text { social place, with an emphasis on sustainability, } \\
\text { content diversity and preservation of its genius loci. }\end{array}$ \\
\hline
\end{tabular}

Source: own.

Table 2.

List of collaboration practices. 
To this question, we obtained various answers. In three cases, the initiator is a non-profit partner (employment, abandoned properties and education), and once (health) the municipality feels the hierarchical relationship but the initiator is the NGO.

In the case of employment, the initiator is the NGO EPIC and the main partner is the municipality of Zvolen (approx. 43,000 inhabitants). Other institutions involved in the project are state/public educational institutions (schools), as well as entrepreneurs and companies-potential employers for young people, or other non-profit organisations dealing with youth work. An important partner in this project is the municipality of Turku in Finland which shares their know-how with Youth Guarantee programme and provides examples of best practices. The programme has managed to form a working group composed of a wide range of actors that are essential in elaborating on or influencing the employment of youth in the region. It aims to change the regional public policy of guarantees for youth. All partners are equal in this initiative.

In the area of education, the initiator is the Children of Slovakia Foundation, motivated by the low financial literacy of people in Slovakia caused by the changes of the financial markets after 1990, in the words of project manager: 'A new system of the functioning of the state came into being prior to which the people had enjoyed "the security" guaranteed by the state and limited financial products offered by one bank; the market changed and the people failed to respond to those market changes, the elderly were unable to adapt and teach the young ones; new banking products appeared along with non-banking sector companies and people were bewildered by the choices, were easily duped and fell prey to fraudsters'. The School of Family Finance is the first community project about financial literacy in Slovakia with accreditation from the Ministry of Education, Science, Research and Sport of the Slovak Republic. Apart from the accreditation, it is hard to talk about any cooperation with the public sector. The project manager visited the Ministry of Labour, Social Affairs and Family, the Ministry of Education and the Office for Minorities; however, no one expressed the desire to enter into cooperation, because they would not accept the methodology already developed by experts from the third sector. They displayed an unwillingness to cooperate on the product as they wanted to apply their own methodology. Yet another problem perceived by the project manager was the non-acceptance of the third sector by the government. Thus, the impact on changing public policies is difficult or even impossible at this moment.

In the case of health, the view from the municipality is that the accountability and responsibility are on the town, and therefore, they are at the top of the hierarchy: 'I would characterise the nature of our relationship as that of a common fulfilment of predetermined goals. It is difficult to talk about full equality in terms of the hierarchy of relations, because self-government has roles and competencies defined by law. So, there is a degree of commitment and responsibility towards citizens, to fulfil the roles and tasks. NPOs perform the tasks voluntarily and the degree of responsibility in relation to citizens is of a different nature. The NPOs may be at the top in terms of expertise, it is closer to the community, but in terms of accountability, the town plays a bigger role' (the municipality representative). Also, the NGO feels the responsibility for those public services for the disabled is on the town's shoulders, but they do everything in order to serve their target group: 'We are perceived as both initiator and co-implementer; we have initiated a number of discussions (e.g. education and inclusion of autistic children). The nature of relationships with the town is perceived as a division of tasks according to expertise-we actively seek pathologies in the community and try to work with them, the town creates a platform for solving these problems, that is., by providing grants and subsidies, supporting projects, community development via community 
centres, etc. This all helps to integrate the target group into society'. In this case, the municipality is forming the local public policy in the field of social services together with the NGO.

The public spaces issue, specifically the abandoned public amphitheatre, which was on the list of non-usable properties, was also initiated by the NGO. It all started as an informal group of young people who organised the first screening in the amphitheatre in the summer of 2011, and the intention was to draw attention to a place that has its own value. The struggle for the preservation of the amphitheatre has gradually become a key activity for this informal group leading to a series of events: an open call for help, collecting signatures on a petition, art amphitheatre, concerts for the Amphitheatre and Week of Urbanism. This led to the founding of the NGO in 2013. At first, the municipality did not trust the young people, but they signed a co-operation memorandum with the NGO and asked for the concept of what the NGO would like to do with the amphitheatre, including the financial plan in the following three months. After the concept had been delivered, the city leadership changed their minds and began to trust the NGO. The main activity of Civic Association for the Amphitheatre remains the support of the amphitheatre, whether in the form of organising a summer movie theatre or other events. The initiative has no influence on public policy; however, it has inspired two other organisations to approach the municipality to start dealing with other abandoned properties (a former cinema turned into Urban Spot, old city bastion turned into a literary café). This initiative even has an indirect influence on politicians-the amphitheatre has become a symbol of the city, if any of the councillors wanted to 'do' something with the amphitheatre, it would affect the people in the city-the voters.

\subsection{Drivers and barriers in the collaboration}

To answer the main research question 'What are the drivers and barriers of collaboration', we summarised the responses into Table 3.

Some of the drivers and barriers are explained in depth:

- Solutions that do not require a change in legislation or high financial investment, such as the establishment of a commission whose members would be from different sectors and would set the issue to be addressed within a set period - set priorities, plans and timetables for activities, allocate competencies and responsibilities between the individual organisations to avoid duplication, for example, the Youth Guarantee programme formed a working group of various experts from other NGOs, public sector organisations and companies.

- "Playing in your own sandpit"—individualism. If some areas/topics are dealt with by several institutions, they consider each other as competitors and do not want to cooperate for fear that their competitors will steal the know-how.

- Impact on various communities - there are significant changes in the participants' behaviour regarding financial situation, e.g. death of a family member, poor health, loss of employment, unexpected expenses, etc., and they can cope better with these issues.

- Interest and commitment of the civic association in the creation of policies in relation to the citizens they represent. 
On Relations between Government and Non-profits: The Case of Slovakia

DOI: http://dx.doi.org/10.5772/intechopen.89482

\begin{tabular}{|c|c|c|c|c|}
\hline & Employment & Education & Health & $\begin{array}{l}\text { Abandoned } \\
\text { properties }\end{array}$ \\
\hline \multirow[t]{3}{*}{ Drivers } & $\begin{array}{l}\text { Connecting the } \\
\text { sectors and better } \\
\text { understanding between } \\
\text { various institutions, } \\
\text { companies and } \\
\text { organisations }\end{array}$ & $\begin{array}{l}\text { Impact on various } \\
\text { communities } \\
\text { in different life } \\
\text { situations }\end{array}$ & $\begin{array}{l}\text { Interest and } \\
\text { commitment } \\
\text { of the civic } \\
\text { associations }\end{array}$ & $\begin{array}{l}\text { Drive to revive the } \\
\text { potential of the } \\
\text { place }\end{array}$ \\
\hline & $\begin{array}{l}\text { Looking for solutions } \\
\text { that do not require a } \\
\text { change in legislation } \\
\text { or high financial } \\
\text { investment }\end{array}$ & $\begin{array}{l}\text { Trends from } \\
\text { abroad, e.g., } \\
\text { European Money } \\
\text { Quiz and Global } \\
\text { Money Week }\end{array}$ & $\begin{array}{l}\text { Constructive } \\
\text { discussion and } \\
\text { mutual respect }\end{array}$ & $\begin{array}{l}\text { Self-realisation of } \\
\text { several members } \\
\text { of the NGO } \\
\text { (artists interested } \\
\text { in screenings) }\end{array}$ \\
\hline & $\begin{array}{l}\text { Common will to solve } \\
\text { unemployment }\end{array}$ & $\begin{array}{l}\text { Social need- } \\
\text { public demand }\end{array}$ & Expertise & $\begin{array}{l}\text { Lack of space } \\
\text { for cultural } \\
\text { activities-public } \\
\text { demand }\end{array}$ \\
\hline \multirow[t]{4}{*}{ Barriers } & Legislation & $\begin{array}{l}\text { Unwillingness } \\
\text { of Ministries for } \\
\text { deeper cooperation }\end{array}$ & $\begin{array}{l}\text { Limited } \\
\text { competences of } \\
\text { officials }\end{array}$ & $\begin{array}{l}\text { Mistrust of the } \\
\text { municipality in } \\
\text { the beginning }\end{array}$ \\
\hline & $\begin{array}{l}\text { Finance—lack of } \\
\text { resources }\end{array}$ & $\begin{array}{l}\text { Finance-lack of } \\
\text { resources }\end{array}$ & $\begin{array}{l}\text { Finance-lack of } \\
\text { resources }\end{array}$ & $\begin{array}{l}\text { Finance-lack of } \\
\text { resources }\end{array}$ \\
\hline & Bureaucracy & \multirow[t]{2}{*}{$\begin{array}{l}\text { The time factor } \\
\text { (setting the } \\
\text { learning cycles } \\
\text { from a time } \\
\text { perspective) }\end{array}$} & $\begin{array}{l}\text { Hidden } \\
\text { prejudices in } \\
\text { society towards } \\
\text { the disabled }\end{array}$ & \multirow[t]{2}{*}{$\begin{array}{l}\text { A lease contract } \\
\text { for } 30 \text { years which } \\
\text { can be cancelled } \\
\text { any time by the } \\
\text { municipality }\end{array}$} \\
\hline & Individualism & & $\begin{array}{l}\text { Lack of a } \\
\text { qualified } \\
\text { workforce }\end{array}$ & \\
\hline
\end{tabular}

Source: own.

Table 3.

Drivers and barriers identified by respondents.

- Officials are willing and able to communicate only within the scope of their competence; however, within the scope of the laws that they use in their work, by which they are governed, they are unable to cooperate.

- Qualified workforce for children with autism (e.g., school assistants are lacking). Formally, criteria are met, e.g. by creating positions of assistants in schools, but to what quality are these services implemented? Legislation is set well, but is not enforceable due to a lack of resources.

\section{Conclusion}

The creation of municipal self-governments is an important issue also from the point of view of the existence of NPOs in Slovakia. Municipalities may take decisions independently and act in all matters pertinent to the administration of the municipality and its property, if a special law does not assign such acts to the State or to other legal bodies or individuals. Their decisions and ordinances may be superseded or invalidated only by Parliamentary Acts or, if illegal, by courts. Already in 1990, municipalities were allocated with many responsibilities 
(including important tasks in investigated areas of education, employment, health and public spaces), and they have full freedom to decide to what extent to involve civil and non-profit sector into the delivery of the abovementioned services as the scope and method of discharging those responsibilities are independently decided by municipalities. It also helps the municipalities to ease the economic burden-the responsibilities were passed to the municipalities from the state, but the public budgets allocated from the state are not sufficient enough to fund all the responsibilities. Cooperation with NPOs helps municipalities, and mostly thanks to the amount of volunteer work from NPOs, the costs are reduced. Also, the services provided by NPOs are complementing the public services provided by the municipalities; in many cases, the NPOs replace the municipality completely.

Under these conditions and in order to discharge their responsibilities, from the beginning, municipalities started to co-operate with the non-profits in many different ways - from simple non-monetary co-operation, via the provision of financial grants, to the contracting and outsourcing of some services to NPOs. However, none of these forms of cooperation were undertaken in a fully systematic way and the concrete conditions differ between municipalities. Many municipalities invite non-profit organisations to participate in the local policy making processes, accepting their expertise and position of core local stakeholders. Such participatory processes deepen democracy and bring positive social impact. Non-profits can only fulfil their potential when embedded in supportive policy environment.

\title{
Acknowledgements
}

This research was funded by the VEGA project 'Abandoned Slovakia: Effective solutions to the creative reuse of used properties in non-urban areas, grant number V-18-101-07-101312'.

\author{
Author details \\ Mária Murray Svidroňová \\ Faculty of Economics, Matej Bel University, Banska Bystrica, Slovakia \\ *Address all correspondence to: maria.murraysvidronova@umb.sk
}

IntechOpen

(C) 2019 The Author(s). Licensee IntechOpen. This chapter is distributed under the terms of the Creative Commons Attribution License (http://creativecommons.org/licenses/ by/3.0), which permits unrestricted use, distribution, and reproduction in any medium, provided the original work is properly cited. (cc) BY 


\section{References}

[1] Cohen JL. American civil society talk. Philosophy and Public Policy Quarterly. 1998;18(3):14-19

[2] Defourny J. From third sector to social enterprise. In: Borzaga C, Defourny J, editors. The Emergence of Social Enterprise. London, New York: Routledge; 2001. pp. 1-28

[3] Wijkström F, Zimmer A. Nordic Civil Society at a Cross-Roads: Transforming the Popular Movement Tradition.

Baden-Baden: Nomos; 2011

[4] Pestoff V. A Democratic Architecture for the Welfare State. London, New York: Routledge; 2008

[5] Paton R, Spear R. Civil Society and the "Commanding Heights": The Civil Economy: Past Present and Future [Internet]. 2010. Available from: https://d1ssu070pg2v9i.cloudfront. net/pex/carnegie_uk_trust/2016/02/ pub1455011697.pdf [Accessed: 2019-06-06]

[6] Borzaga C, Depedri S, Galera G. Interpreting social enterprises. Revista de Administração. 2012;47(3):398-409

[7] Hulgård L. Social enterprise and the third sector-Innovative service delivery or a non-capitalist economy? In: Defourny J, Hulgård L, Pestoff V, editors. Social Enterprise and the Third Sector: Changing European Landscapes in a Comparative Perspective. London, New York: Routledge; 2014. pp. 82-100

[8] Vaceková G, Svidroňová M. Nonprofit Organizations in Selected CEE Countries: A Journey to Sustainability. Brno: Masaryk University; 2016

[9] Salamon LM, Sokolowski W. The Third Sector in Europe: Towards a Consensus Conceptualization. Third Sector Impact Project Working Paper. 2014
[10] Defourny J, Nyssens M. How to bring the centres of gravity of the non-profit sector and the social economy closer to each other. Voluntas: International Journal of Voluntary and Nonprofit Organizations. 2016;27:1546-1561

[11] Defourny J, Hulgård L, Pestoff V, editors. Social Enterprise and the Third Sector: Changing European Landscapes in a Comparative Perspective. London, New York: Routledge; 2014

[12] Hulgård L. Differing perspectives on civil society and the state. In: Laville JL, Young DR, Eynaud P, editors. Civil Society, the Third Sector and Social Enterprise: Governance and Democracy. London, New York: Routledge; 2015

[13] Klein JL, Tremblay DG, Bussières DR. Social economy-based local initiatives and social innovation: A Montreal case study. International Journal of Technology Management. 2010;51(1):121-138

[14] Nicholls A, editor. Social Entrepreneurship: New Models of Sustainable Social Change. Oxford: OUP Oxford; 2008

[15] Mair J. Social entrepreneurship: Taking stock and looking ahead. In: Fayolle A, editor. Handbook of Research on Social Entrepreneurship. Cheltenham: Edward Elgar Publishing Limited; 2010

[16] Andersen LL, Hulgård L . Social Entrepreneurship and Social Innovation, Nordic Council of Ministers: Social entrepreneurship and Social Innovation. Initiatives to Promote Social Entrepreneurship and Social Innovation in the Nordic Countries. Denmark: Norden; 2015

[17] Bacchiega A, Borzaga C. Social enterprises as incentive structures. In: 
The Emergence of Social Enterprise. Vol. 273. London, New York: ROUTLEDGE in association with GSE Research; 2001. pp. 273-295

[18] Borzaga C, Defourny J, editors. The Emergence of Social Enterprise. London, New York: Psychology Press, Routledge; 2004

[19] Mair J, Noboa E. Social

Entrepreneurship: How Intentions to Create a Social Enterprise Get Formed. IESE Working Paper D/521. 2003.

[20] Pestoff V. Hybridity, coproduction, and third sector social services in Europe. The American Behavioral Scientist. 2014 Oct;58(11):1412-1424

[21] Nicholls A, Daggers J. The Landscape of Social Impact Investment Research: Trends and Opportunities. Oxford: SBS Oxford; 2016

[22] Laville JL, Salmon A. Rethinking the relationship between governance and democracy. In: Laville JL, Young DR, Eynaud P, editors. Civil Society, the Third Sector and Social Enterprise: Governance and Democracy. Oxfordshire: Routledge; 2015. p. 200:145

[23] Laville JL. The social and solidarity economy: A theoretical and plural framework. In: Social Enterprise and the Third Sector. London, New York: Routledge; 2014. pp. 118-129

[24] Gaiger LI, Ferrarini A, Veronese M. Social enterprise in Brazil: An overview of solidarity economy enterprises.

Retrieved February. 2015;13:2017

[25] Polani K. The Great Transformation: The Political and Economic Origins of Our Time. New York: Rinehart; 1944

[26] Laville JL, Lemaître A, Nyssens M. 17 Public policies and social enterprises in Europe: The challenge of institutionalization. In: Nyssens M, editor. Social Enterprise: At the Crossroads of
Market, Public Policies and Civil Society. Oxfordshire: Routledge; 2006. pp. 272-294

[27] Fraser N. A triple movement? Parsing the politics of crisis after Polanyi. In: Beyond Neoliberalism. Cham: Palgrave Macmillan; 2017. pp. 29-42

[28] Yunus M. Banker to the Poor: MicroLending and the Battle Against World Poverty. New York: PublicAffairs; 2007

[29] McKeown-O’Donovan A, Solidarity LK. Unpublished Manuscript for Solidus-Work Package. Vol. 12015

[30] Mauss M. The Gift: The Form and Reason for Exchange in Archaic Societies. London, New York: Routledge; 2002

[31] Voorberg WH, Bekkers VJ, Tummers LG. A systematic review of co-creation and co-production: Embarking on the social innovation journey. Public Management Review. 2015;17(9):1333-1357

[32] Brandsen T, Pestoff V.

Co-production, the third sector and the delivery of public services: An introduction. Public Management Review. 2006;8(4):493-501

[33] McLaughlin K, Osborne SP, Ferlie E, editors. New Public Management: Current Trends and Future Prospects. London, New York: Psychology Press; 2002

[34] Osborne SP. Introduction the (new) public governance: A suitable case for treatment. In: The New Public Governance? London, New York: Routledge; 2010. pp. 17-32 
Section 4

\section{Financial Aspects of Non-Profit Organisations}





\title{
Planning the Audit of Financial Resources in a Non-Profit Organization
}

\author{
Tatjana Horvat and Vito Bobek
}

\begin{abstract}
Internal auditing of non-profit organizations represents the first line of defence against inadequate use of non-profit organization's funding sources. In the European legal system, the purpose of a non-profit organization is to meet the needs of stakeholders with different products and services and public works that the state or other profit organization cannot satisfy and to affect the policy of the state or the economy. Non-profit organizations due to their nature are not able to acquire their own sources of financing, which is why they largely depend on subsidies, grants, membership fees, revenue from the sale of services and products that are not necessarily sold at market price. Therefore, the correct usage of these sources is all the more important. One way of checking the correctness of the use of sources of financing is internal audit, which must be carefully planned. The purpose of the chapter is to present the planning of the internal audit in the case of a non-profit organization, the most important part of which is the definition of audit objectives, the organization's risk analysis and the preparation of the audit plan.
\end{abstract}

Keywords: non-profit organization, audit, COSO, financing, legislation

\section{Introduction}

The biggest financial challenge of a non-profit organization is to implement all its programs and to meet the needs of both users and financiers. "The interdisciplinary aspect of non-profit organizations' research is a reflection of the distinctive nature of non-profit organizations, the distinctive nature of non-profit organizations, the complexity of their operations and their relationships with their environment, and the difficulties of defining the boundaries of NPO activity and determining, categorically, what is and what is not a non-profit organization" [1]. Non-profit organizations could be funded by different finance sources, for example, the state (ministries), municipalities, parents, donors, institutions, and others. Funding problems can arise when the state devotes, for many years, equal or even, less financial resources for financing non-profit organizations. In some countries, for example, the state's financial resources are strictly dedicated and are intended to cover wages and material and indirect costs of a non-profit organization. Usually no financier, with the exception of the, for example, FIHO Foundation, finances fixed assets, which means that a nonprofit organization must provide, for all equipment it needs, from its own funds or donations. A non-profit organization can be financed by various types of public 
resources; therefore, transparency of this funding must be ensured, and one way is to monitor external funding of non-profit organizations by the so-called internal audit. An internal auditor is either a person employed by an organization (in the case of major non-profit organizations) or a person outside the organization. In any case, it must be authorized for internal auditing.

For each audit, an internal auditor shall prepare a plan for carrying out the audit or an internal audit plan. In planning a particular transaction, internal auditors should handle with the necessary professional due diligence. Planning work focuses on key areas that have a significant impact on the correctness and rationality of operations and/or the purpose of using budget funds.

The plan shall specify at least:

- Subject (area) and scope of an audit

- The purpose and objective of an internal audit

- Significant risks to an audited area/process and data on their control

- Criteria to be used in the implementation of each audit

- Predicted scope and method of work

- Deadlines for starting and completion of the implementation and preparation of the final audit report

- Persons to whom the final audit report will be sent

\section{The purpose and methods of work}

The chapter aims to examine the regularity of financing in accordance with laws and regulations. We will use the theoretical framework and study case's outcomes to compile recommendations for non-profit organizations on how to use finance resources in accordance with the rules. We will focus on a singular study of internal audit of financing a social entity, and this is the non-profit organization in Slovenia, working in pre-educational children programs.

We set the following research question: How internal controls in using financial resources in the non-profit organization work?

The research will be qualitative with using the audit method of internal control surveys: it is the COSO II.

\section{Definition of the purpose and objectives of an internal audit engagement}

Effective internal auditing of non-profit organizations represents the first line of defense against inadequate use or management of public funds [2].

The purpose of an internal audit can be defined [3]:

a. Investigating and evaluating the adequacy, effectiveness, and quality of the operation of the internal control system

b. Providing reliable and impeccable information 
c. Ensuring compliance with guidelines, plans, laws, and other regulations

d. The protection of property

e. Ensuring the efficient and efficient use of resources

f. Achievement of the set goals and objectives related to business or programs and continuous improvement of the performance of the basic business functions of the direct user of the budget

As the purpose of an internal audit of the financing of the activities of an educational institution, the aforementioned definitions apply in the previous paragraph. We will focus on financing the non-profit organization, in accordance with the guidelines, plans, laws, and other regulations of the financing process.

We can say that the goals are derived from the purpose. As defined by the standards, the objectives (Operation Standard 2210) must be defined for each job.

Based on the business goals at organizational level and audit units, opportunities and disadvantages in an organization that influence the setting up and realization of business desires, the initial assessment of the management of business risks and the internal control system, the internal auditor sets the work goals and defines the further scope and conditions for the realization of an internal audit function [4].

Each management of the non-profit organization (in our case the management represents one person) is responsible for the legality of operations and, in this regard, also for the prevention and detection of operations incompatible with legal norms. In doing so, the management can help with the following orientations and procedures [5]:

- Monitors the regulatory requirements and provides procedures that enable compliance with legal regulations

- Ensuring proper regulation and operation of internal control

- Develops, publishes, and respects the code of conduct of all employees in the company

- Ensures the development of human resources and the understanding and respect of the code of conduct

- Monitors compliance with the code of business conduct and disciplinary action against employees who do not respect it

- Employs appropriate experts to help establish and monitor prescribed solutions

- Keeps an up-to-date list of important regulations and explanations that they have to respect when doing business

\section{Creating a work program}

Internal auditors must develop and document a work program to achieve the business objectives (Standard 2240). Work programs must include procedures 
for identifying, studying, evaluating, and documenting information during the course of the transaction. The work program must be approved before the implementation, and each adjustment must be approved immediately (Standard 2240.A1).

An engagement work program is a document listing the procedures to be followed at work to fulfill its plan [6].

A well-prepared work program [7]:

- Provides a general overview of the work that will be carried out and facilitates the understanding of the audited entity

- Provides evidence that the work is properly planned

- Provides a document for the management review

- Assures that all risks are adequately addressed

- Assist in supervising work

- Edits and links the audit

The auditee is a non-profit organization X. In our case, the basis for the commencement of the internal audit is the rules on the operation of the joint internal audit service in the municipality and the annual plan for auditing this municipality for 2018. The basis for the internal audit of non-profit organization $\mathrm{X}$ is the strategic plan of the municipality's internal audit from 2015 to 2020. Both the strategic (long-term) and the annual audit plans are approved by the mayor of the municipality. On the basis of the strategic and annual audit plan for 2018, an internal audit of the financing of activities for non-profit organizations $\mathrm{X}$ for 2018 will be carried out.

The annual plan of the internal audit of the municipality is based on an initial assessment of the risks of doing business in a non-profit organization, based on the examination of the organizational structure, business-organizational rules, questionnaire, and self-assessment of the auditee [4]. The process of initial assessment of business risks includes the following steps:

- Identification of important areas of the organization's business

- Identification of possible risks within the framework of individual areas

- Assessment (evaluation) of individual risks

- Common risk assessment

The initial assessment of the risks of non-profit organization X showed that the priority in internal auditing has an area that relates to the coherence of financing public non-profit organization's activities with internal and external regulations. The public service activity is financed from the state budget, municipal budget, and parent payments.

Based on municipality policies and plans, an internal auditor who audits nonprofit organization X must make a so-called internal audit plan that contains the purpose, scope, and objectives of the audit, the expected results, implementation times, deadlines, and employees; it is shown in Table 1. 


\begin{tabular}{|c|c|c|c|}
\hline $\begin{array}{l}\text { Title of the } \\
\text { material }\end{array}$ & \multicolumn{3}{|c|}{ Plan for the implementation of an internal audit of non-profit organization $\mathrm{X}$} \\
\hline $\begin{array}{l}\text { The purpose of } \\
\text { the internal audit } \\
\text { task }\end{array}$ & \multicolumn{3}{|c|}{$\begin{array}{l}\text { The purpose of the internal audit activity is to improve the legality of financing the } \\
\text { activities of the non-profit organization, thus improving the possibilities of } \\
\text { achieving the goals of non-profit organization } \mathrm{X} \text { and increasing its added value }\end{array}$} \\
\hline $\begin{array}{l}\text { The subject of } \\
\text { internal audit }\end{array}$ & \multicolumn{3}{|c|}{$\begin{array}{l}\text { Assessment of the lawfulness of the financing of non-profit organization activities } \\
\text { in } 2018 \text { in the context of the provision of public services, the verification of the } \\
\text { operation of internal controls, and the management of risks in this field }\end{array}$} \\
\hline Revised period & \multicolumn{3}{|l|}{ Year 2018} \\
\hline $\begin{array}{l}\text { Definition of } \\
\text { risks }\end{array}$ & \multicolumn{3}{|c|}{$\begin{array}{l}\text { The key risks are broken down as follows: } \\
\text { - The risk of the internal environment } \\
\text { - The risk of inappropriate targets } \\
\text { - The risk of not recognizing risky events by management } \\
\text { - The risk of inadequate risk assessment } \\
\text { - The risk of inadequate risk management } \\
\text { - The risk of inadequate control activities in the process of financing preschool } \\
\text { education activities } \\
\text { - The risk of inadequate information and communication } \\
\text { internal control in the process of financing the activities of preschool } \\
\text { education }\end{array}$} \\
\hline Audit criteria & \multicolumn{3}{|c|}{$\begin{array}{l}\text { The legality of financing the activities of preprimary education is assessed on the } \\
\text { basis of the criterion whether non-profit organization X was subject to the } \\
\text { provisions of external legal and professional rules and internal business- } \\
\text { organizational regulations governing the financing of the non-profit organization }\end{array}$} \\
\hline $\begin{array}{l}\text { Description of } \\
\text { scope of auditing }\end{array}$ & \multicolumn{3}{|c|}{$\begin{array}{l}\text { The internal audit will include a review of the legality of the financing of the } \\
\text { activities and will therefore review the following: } \\
\text { - The legal bases that apply to the subject of internal audit } \\
\text { - Internal policies } \\
\text { - Instructions from the municipality in the field of financing the public service } \\
\text { of the non-profit organization } \\
\text { - The founding act } \\
\text { - Website of the non-profit organization } \\
\text { - Organization of non-profit organization } \\
\text { - Personal staff folders } \\
\text { - A record of the mission, plans, and goals of the non-profit organization } \\
\text { - Invitations and minutes of the meetings of the council of non-profit } \\
\text { organization X } \\
\text { - The decisions of the council of non-profit organization X regarding the } \\
\text { financing of activities } \\
\text { - Bookkeeping documentation related to the financing of non-profit } \\
\text { - Exganization X } \\
\text { - Report of non-profit organization X } \\
\text { - Requests for payment } \\
\text { - Other documentation }\end{array}$} \\
\hline \multirow[t]{3}{*}{$\begin{array}{l}\text { Plan of audit } \\
\text { rates }\end{array}$} & \multicolumn{3}{|c|}{$\begin{array}{l}\text { The internal audit will be carried out by an internal auditor from the joint internal } \\
\text { audit department of municipality } Z \text {, and its implementation will be supervised by } \\
\text { the head of that service. The implementation schedule is as follows: }\end{array}$} \\
\hline & $\begin{array}{l}\text { The level and content of the implementation of the internal } \\
\text { audit }\end{array}$ & $\begin{array}{l}\text { Number } \\
\text { of days }\end{array}$ & $\begin{array}{l}\text { Time } \\
\text { frame }\end{array}$ \\
\hline & $\begin{array}{l}\text { Job planning } \\
\text { - Elaboration of the implementation plan of the audit } \\
\text { - Acquainting with basic information on the field of } \\
\text { auditing } \\
\text { - Reviewing and updating a permanent folder and } \\
\text { preparing a current folder for the audited area on } \\
\text { which the audit task will be carried out }\end{array}$ & 7 days & $\begin{array}{l}\text { From day } \\
\text { day }\end{array}$ \\
\hline
\end{tabular}


- Announcement and opening interview with the responsible person for the audited area

- Preparation of a work program

Job execution
- Identifying information
- The examination and evaluation of audit evidence
- Preparation of working material
- Preparation of the findings of the internal audit

Deadlines for Creating a draft report:

creating a report Receiving comments from the principal and the accounting officer on the draft report:

Creating a final report:

Recipients of the The draft report is received by

report

- Director of non-profit organization X

- Accountant of non-profit organization X

- Head of the joint internal audit service in municipality Z

The final report is received by

- Director of non-profit organization X

- Accountant of non-profit organization X

- Head of the joint internal audit department in municipality $\mathrm{Z}$

- Mayor of municipality Z

Expected added For the municipality

value of the

performed

internal audit

- Ensure the regularity of the funding of an indirect budget user in the field of preschool education or public service activities

For internal auditors

- To refine and upgrade knowledge for auditing in the field of financing the activities of the indirect budget user-the public institution

- To formulate a plan for the implementation of the internal audit activity and a work program which will be a direction for future internal audits in the field of financing public service activities

Source: Own.

Table 1.

An example of an internal audit plan.

\section{Results of the case study and discussion}

In the continuation of the article, we provide some of the more important findings from the internal audit of each of the eight components of the model COSO II, whereby the financing of the activities of non-profit organization $\mathrm{X}$ is revised. Internal environment, setting goals, recognition of risk events from the management's side, risk assessment, risk control, communication, and monitoring (they are all parts of the COSO method) were evaluated on the basis of interviews, 
observations, verification, and examination of relevant documentation, all in accordance with the work program. In accordance with the audit plan, we have evaluated the control activities according to the audit plan in the phases inside the financing activities of non-profit organization $\mathrm{X}$ on the basis of the selection of a nonstatistical sample of documents or data and the review and comparison of data in order to obtain the appropriate ground for providing assurance about properly established and functioning internal controls.

\subsection{First component of COSO II: evaluation of the control environment (internal environment)}

From the examination of the control environment, we could find out how much employees are aware of the need for internal control, how the control environment ensures the possibilities for the operation of internal controls in the field of financing activities of non-profit organization $\mathrm{X}$, and what basis it represents for the functioning of the other components of the COSO.

In order to verify the internal control environment, we carried out the following methods of work:

- Verification of the existence of a code of ethical conduct and verification of the signature of the responsible person

- Checking employees' knowledge of the code of ethical conduct and how to get acquainted with it, interview with employees (sample), and verification on a sample of employment contracts (nonstatistical sampling)

- Verification on a sample of contracts of employment and on a sample of colleagues' minutes (non-static sampling)

- Acquisition and review of the act on the job classification system in comparison with the law on societies, the act on establishment, and the rules on norms and personnel conditions for performing preschool education activities

- Acquisition and review of the act on the job classification system

- Acquisition and examination of other internal acts

- Employee sample interview in the process of financing activities (nonstatistical sampling)

- Acquisition and verification of the act on job classification and attendance and absence

- Check on the sample of how the substitution took place during the absence (non-static sampling)

- Interview with headmaster X

- Examining plans and reports

- Selection of the sample and examination of college minutes

- Examining the act on the job classification system 
- Examining documentation on employee replacement and sick leave. Examination of ownership of internal control procedures and rules on circulation of bookkeeping documents

- Acquisition and review of the annual report and the report on work in the school year

- Obtaining and studying the development plan, educational plan and examining the annual work plan and the financial plan

- Verification of records of the parents' council, minutes of conferences and colleges of employees and examination of the annual report

We show the following findings by the components of the control environment:

- Irreproachableness and ethical values: non-profit organization X passed a code of ethics which has been signed by the management of the non-profit organization, which is internal control at the level of the organization. The code is divided into four basic areas of peoples' responsibility, who are directly or indirectly involved in the care of the child within the non-profit organization. The workers' responsibilities in the non-profit organization are responsibility to the children, responsibility to the parents and families, responsibility to work organization and colleagues, and responsibility to the wider community. The employees of the non-profit organization are familiar with the abovementioned code at the annual conference of all employees in non-profit organization $\mathrm{X}$, which is evident from the records of the conclusions of the annual conference and from the sample of five signed employment contracts, where the employees commit themselves to comply with the aforementioned code. From the interviews of randomly selected four employees (teacher 1, teacher 2, cook, business secretary), we understand that the employees are aware that they must respect integrity and ethical values and that there are measures in case of noncompliance with the said code. The latter is examined on a sample of 10 records of weekly board meetings, with 1 record containing an increase in awareness in the case that the non-profit organization staff must separate what they say on behalf of the institution from their own opinion. Internal controls in the field of integrity and ethical values are assessed as appropriate from the internal auditor's view.

- Commitment to the skills and human resource management: non-profit organization $\mathrm{X}$ is at the level of the organization ready and has a so-called act on the job classification system signed by the management of the organization, which is updated with the law on organization and financing of education, which explicitly stipulates in Article 108, that the systematization of non-profit organization jobs is determined by the director in agreement with the founder, on the basis of prescribed norms and standards (rulebook on norms and personnel conditions for performing preschool education activities). After examining the act on job systematization, we have learned that it is in line with the aforementioned regulations and that it is adopted at the municipal council of the municipality. When examining internal controls at the level of the process, we find out that the act on the systematization of jobs, the rules on accounting, and the book of rules on the circulation of accounting defined system of authorizations and responsibilities of the following working posts of employees in the process of financing activity X, president, assistant president, 
accountant, bookkeeper, and business secretary. We check the performance of the authorization system in the next steps. On the last page of the rules on accounting and the rules on the circulation of bookkeeping documents with their own signature, the abovementioned employees confirmed that they are familiar with the said rules. We also find the latter on the basis of interviews with them. The act on the job classification system also defines the replacement during the absence (who replaces who); we also check the operation by taking the month of August for 2018 and checking the presence and the replacement of employees participating in the financing process; we check the presence and replacement of employees who are involved in the activity financing process of non-profit organization X. During this period, the management of the organization is absent (14 days in the month of August) and was replaced by the assistant director and vice versa; the bookkeeper replaced the accountant, as determined in the act. From the presence and absence records, it is evident that the absences are planned, which ensures the smooth running of the work process. We consider the internal controls appropriate from the internal audit's view.

- Philosophy of leading and way of functioning: on the basis of an interview with the management we verify, if he/she is aware that risk management, internal control, and internal auditing for non-profit organization $\mathrm{X}$ is a useful process, we come to see that the management possesses this awareness; she has acquired it primarily by various training courses for school principals and nonprofit organizations. From the interview we also find out that the management, together with the management's assistant, plans tasks in non-profit organization $\mathrm{X}$ with the intent to achieve the objectives of non-profit organization $\mathrm{X}$; this is evident from the annual work plans for non-profit organization for 2018 and a financial plan prepared for the calendar year 2018. Both plans are confirmed by municipality $\mathrm{Z}$. The management occasionally discusses the tasks and objectives on regular weekly councils, as can be seen from the sample of records of 10 weekly council meetings. We evaluate internal controls as appropriate from the internal audit's view.

- Organizational structure: the organizational structure of non-profit organization $\mathrm{X}$ is determined in accordance with the act of the systematization of jobs and the rules on norms and personnel conditions for performing activities of preschool education, and this is handled appropriately. These regulations also specified the number, qualifications, and replacement of employees in the process of financing the activities of non-profit organization $\mathrm{X}$. We compare the job description, as recorded by the rules on job classification system, with the actual occupation of the workplace, so we learn the following, the level and the direction of the professional education, special conditions or additional skills and competences, organizational field or occupation, type and extent of the responsibility of civil servants occupying the post, and working conditions and other attributes and characteristics. From the interview with the management, we recognized that the management realizes the responsibility and dedication of employees involved in the process of financing activities of the non-profit organization. We evaluate the internal controls as appropriate from the internal audit's view.

- Responsibility: according to the Public Finance Act, non-profit organization X must prepare a so-called annual report on the achieved objectives and results, where, among other things, it reports on an annual basis an assessment of 
the functioning of the internal financial control system, where it actually briefly reports on the situation in the field of risk management, internal control, and internal auditing, but it also reports on risk management in the work report for the school year. An annual reporting is set up; both reports are discussed by the board of the institution when the school year or calendar year is concluded [8].

We find that there is no regular reporting within the school or calendar years for employees to whom risks and internal controls apply; therefore we are assessing this internal control as partially appropriate.

\subsection{Second component of COSO II: evaluation of business goals}

Leadership must have known and attainable business goals, and their evaluation is needed, so it is possible to know the orientation and business events that influence the achievement of the goals that are set [9].

Non-profit organization $\mathrm{X}$ has long-term and short-term goals of operation written in a strategic sense, written for 5 years in the so-called management's development plan. The management prepares it with the help of other employees. The legal basis of the development plan is in the law on organization and financing of education (ZOFVI, Ur. 1. RS 16/2007-UPB5, 48 and 49. article). We conclude that operational goals are set in the development plan based on strategic objectives in the annual work plan for the selected school years and in the financial plan for the calendar year. The development plan was presented and discussed by working groups in April and May 2018, so that the employees are familiar with it. The development plan is passed by the Council of the Institute; there is an agreement passed in this regard by the institute. Monitoring and implementation of planned descriptive tasks by individual areas are carried out by the management, assistant management, counseling worker, and heads of individual departments. The analysis is carried out twice per year in January and June 2018 at educational assemblies, professional working groups, house working groups, and development teams where relevance and efficiency of these and the introduction of necessary changes and improvements are determined. In this aspect there are meeting records in January and June 2018; we also hold interviews with five randomly selected employees (educator, cook, business secretary, consultant) from whom it is evident that they are acquainted with the descriptive goals from the internal audit's view X, not in detail, but know how to find documents from the field of planning of organization $\mathrm{X}$ in the intranet of non-profit organization $\mathrm{X}$, which is intended for internal communication of employees. Non-profit organization $\mathrm{X}$ is reporting on the achievement of the descriptive goals and causes for the derogation in the 2018 annual report. I find that non-profit organization $\mathrm{X}$ is monitoring financial objectives only once per year, in the 8-month business report. Therefore, we estimate that internal controls in the field of objectives are partially appropriate from the internal audit's view.

\subsection{Third component of COSO II: identifying unwanted events}

Recognizing (identifying) internal and external events is necessary to learn about opportunities and threats and the advantages and disadvantages that affect the achievement of business objectives.

In order to verify the identification of adverse events in the organization, we carried out the following methods of work: 
- Obtaining and examining the contents of the risk register and the annual report

- Examining the risk register in terms of legal financing of the organization

- Interview with a sample of employees about risk awareness in the field of financing X's activities

- Examining internal policies and risk register in terms of legal financing of the organization

The non-profit organization records the unwanted events related to the process of financing activities in the risk register of 2018 and in the business part of the annual report for 2018. Based on these statements, we estimate that internal controls are appropriate from the internal audit's view.

\subsection{Fourth component of COSO II: assessment of the assessment and management of business risks}

In order to verify the identification of risks in the organization, we examined the risk register and the annual report from the viewpoint of legal financing of nonprofit organization $\mathrm{X}$.

Based on the examination of the risk register, we find that risks in non-profit organization $\mathrm{X}$ are defined and assessed in the risk register, where the risk response is also defined. Non-profit organization $\mathrm{X}$ has defined risks in the implementation of education programs, in the field of profit/non-profit activity, financial accounting, purchasing, physical security and security of digitized data, investment activities, provision of information support, human resources and recruitment, library activities, property, public commission, and external risks, like the risks of changes in legislation and regulations; it is important to strictly comply with legislation and other regulations and rules for legitimate financing of activities.

The risk register is from 2018 and is available to other employees on the intranet, before that there was a register of risks from 2008. Employees who participate in the process of financing activities are signing at the end of the risk register to prove they are acquainted with it. Within the risk register, certain risks are identified and rated related to the audited area, and the way of handling these risks is determined. Based on audit procedures, the obtained evidence on assessment and managing of risks is evaluated as appropriate from the internal audit's view.

\subsection{Fifth component of COSO II: evaluation of control activities}

The evaluation of control activities was carried out on the basis of the process of financing the non-profit organization's activities by showing internal controls and responsibilities, from the point of view of using cash. The objective of assessing the operation of internal controls in the process of using cash was to determine the degree of completeness and reliability of their operation.

In accordance with the working program, we check internal controls of using the cash in salaries, material, and investments. Our starting point is the purposefully used funds and the rules for using the sources of financing for the main purposes, which are salaries, material, small inventory, and services and funds for investment and investment maintenance. For this purpose, we select the annual items in the gross profit balance income and expenses, which are higher than EUR 7500 (nonstatic sampling), and compare this item with their amount in the financial plan. 
In order to verify that there are control activities in the use of financial assets of non-profit organization $\mathrm{X}$, we carried out the following methods of work:

- Verification that the financing agreements with different institutions and donors are signed and valid.

- Examine the compliance of the financial plan of the organization with regulations, starting points, instructions, etc.

- Verification of the rules on accounting, the book of rules on the movement of bookkeeping documents, the act on establishment, and the act on the systematization of jobs, whether they exist, whether they are signed and valid, or refer to the financing of the organization's activities.

- Comparison of the gross balance sheet (comparison of the 760-grant line of the ministry, municipal grant, student payments) with the financial plan.

- Selecting a non-static sample and checking the sample whether the payment requests given to the municipality are substantially and formally relevant (non-static sampling), which means checking the formal correctness (or containing the relevant information on the issue date, etc.), the content correctness (e.g., amount, compliance with the law, calculation of the price of the program, etc.), and the timeliness of the payment requests submitted.

- Selecting a sample of weekly printouts of inflows and outflows, and checking the amounts on the subaccount of the PPA.

- Choice of a sample of overdue claims up to 30 days, up to 60 days, and up to 90 days and verification of the recovery of claims. Selection of the sample and examination of reminders and decisions on execution.

- Overview of a group of accounts of a 12-month short-term trade receivable. Select (nonstatistical) sample of overdue receivables and verification of posting (creating adjustments and impairments).

- Interview with headmaster, interview with accountant, and acquisition and examination of cash flow plan.

- Selecting a sample of annual items in the gross balance sheet of revenues and expenditures exceeding EUR 7500 (nonstatistical sampling) and a comparison of these items with their amount in the financial plan.

- Comparison of the records of employees with employment contract and job classification systematization. Selection of a sample of employment contracts and comparison with data in employee records. Verification of the existence of the signing of the record by the director.

- Selection of employees' sample and substantive verification of data entry from employee records into payroll accounting program. Interview with accountant.

- Comparison of the printed list of gross wages, contributions, and personal income tax through the recapitulation of payments on the sample. 
- Selecting a sample of accounts (non-static sampling) and checking the existence of checks of received invoices and separating the duties of incompatible events.

- Checking the selected sample of accounts and related order forms, delivery notes, and other supporting documents. Verify the book of received invoices.

- Selecting a sample of accounts (nonstatistical sampling) and verifying the existence of the separation of duties incompatible events and the approval of business events.

- Check the traffic report from the UJP for the selected month (company name, TRR number, accompanying documentation, etc.). Verifying the timeliness of payment.

- Verify the contents of the book of received invoices. Selecting a sample of accounts (non-static sampling) and checking the matching of the balance on the accounts of the general ledger, which are also balance sheet items, with the situation in the analytical records.

- Sample selection (nonstatistical sampling) of payment orders and their verification with record-keeping of payments.

- Examination of material distribution and retail inventory records and services provided, cross-check of records.

- Examining the requirements of the PPP-2 for public procurement in the case of investments. Checking and reviewing the needs in the preparation of the financial plan.

- Testing and checking the selected contractors on the sample. Verification of the contract's compliance with the offer. Verification of contract performance. Interview with headmaster. Selecting a sample of accounts (non-static sampling) and checking the existence of controls and separating the duties of incompatible events on the selected sample of received invoices.

- Verify the book of received invoices.

- Verify the contents of the account, supporting documents by monitoring the execution of works on a selected sample of accounts.

- Selecting a sample of accounts (nonstatistical sampling) and verifying the existence of the separation of duties incompatible events and the approval of business events.

- Checking the timeliness of payment.

- Verify the contents of the book of received invoices.

- Selecting a sample of accounts (non-static sampling) and checking the status of accounts in the accounts and cost centers.

- Checking the selected sample of accounts and related order forms, delivery notes, and other supporting documents. 
- Verify the book of received invoices.

- Selecting a sample of accounts (nonstatistical sampling) and verifying the existence of the separation of duties incompatible events and the approval of business events.

- Check the traffic report from the UJP for the selected month (company name, bank account number, accompanying documentation, etc.). Verifying the timeliness of payment.

- Verify the contents of the book of received invoices. Selecting a sample of accounts (non-static sampling) and checking the matching of the balance on the accounts of the general ledger, which are also balance sheet items, with the situation in the analytical records.

- Testing and checking the selected contractors on the sample. Verification of the contract's compliance with the offer. Verification of contract performance. Interview with headmaster. Selecting a sample of accounts (non-static sampling) and checking the existence of controls and separating the duties of incompatible events on the selected sample of received invoices.

- Verify the book of received invoices.

- Verify the contents of the account and supporting documents by monitoring the execution of works on a selected sample of accounts.

- Selecting a sample of accounts (nonstatistical sampling) and verifying the existence of the separation of duties incompatible events and the approval of business events.

- Verify the printout of the traffic on the account from the Public Payment Administration in Slovenia (company name, TRR number, accompanying documentation, etc.).

- Checking the timeliness of payment.

- Verify the contents of the book of received invoices.

- Selecting a sample of accounts (non-static sampling) and checking the status of accounts in the accounts and cost centers.

- Sample selection (nonstatistical sampling) of payment orders and their verification with record-keeping of payments.

- Examining the annual report from the viewpoint of legal funding of the nonprofit organization.

- Acquisition and review of interim business analyses (e.g., offsets, deviations, reasons for deviations from the financial plan) and interim reports from the viewpoint of legal financing of the non-profit organization.

In the continuation of the existing types of controls, we show the results of testing on the basis of a dedicated use of funds. 
When using funds for salaries, we check the employee records as a basis for the calculation of wages and compare them with the employment contract and the job description systematization. Based on an interview with an accountant and a random sample of 10 employees, we check the substantive correctness of data input from the employee records into the payroll program. On the same sample, we check the existence of irregularities in the transfer of salaries into the general ledger by comparing the printed sheets of the amount of gross wages, the amount of contributions, and the recapitulation of payments on the sample.

When using funds, devoted to the material, we check the small inventory of the service on the selected sample of 10 received supplier receipts on the existence and implementation of separation control incompatible events, as set out in the rules of book record circulation. For example, on a selected invoice for an offered service, a signed multiple-signature stamp is located. We check the existence of the signature of a business secretary who is responsible for completing the invoices or order forms and other documentation (We also check their existence), check the existence of a bookkeeper signature that makes a formal check of the account, and check the existence of the signature of the assistant management, who is in charge of controlling received invoices on the basis of concluded contracts with the supplier-to this we check the existence of the service provided. We check the existence of the signature of the accountant who keeps the account of the received invoices and the existence of the signature of the management as the authorized decree giver. On the same sample of invoices based on the extract from the UJP subaccount, we test the authenticity of the payment to the true supplier indicated on the account and the existence of the separation of the duties of incompatible events (payment by two electronic signatures is carried out by the accountant and the management or by the authorized person, the assistant of the management). We also check the consistency between the value date and the payment date. On the selected sample of payment orders, we separately check the existence and appropriateness of posting the paid invoice into the record-keeping of payments. On a selected payment sample, we make a cross-check of the compliance of the material distribution, small inventory, and service records with the material procurement records, small inventory, and services.

When using finances for investment and investment maintenance, we check the randomly selected purchase of equipment worth more than $€ 10,000$ and compliance with the financial plan and the existence of the main steps in the Public Procurement Act. We are examining whether non-profit organization $\mathrm{X}$ is following the main phases of public procurement, namely, whether there is a need for a public procurement plan (financial plan), whether there are tender specifications and documentations, or whether there is a publication for a public tender on the websites of the information portal or in the Official Journal of the European Union (the subject of the public procurement, the value, the quantity, the quality, the delivery deadlines, the selection criteria, the address for information, the time for submission and opening of tenders, and the publication of the results), whether there is a procedure for selecting the most favorable bidder in the audited entity, whether there is a concluded contract and its date. On the selected equipment purchase account, we make a content control, who is the supplier, miscellaneous documentation, and compliance to the rules on separating the duties of incompatible events (check the existence of signatures of the business secretary, bookkeeper, assistant of the management, accountant, management). At the invoice payment, we pay attention to the compliance of the supplier's data in the invoice and program for payment at the UJP; we also compare the payment time and the value time. We check the consistency of posting the selected invoice on the relevant account and the cost spot. 
We estimate that the functioning of internal controls in the field of the lawfulness of financing the non-profit organization in the use of finances is appropriate.

\subsection{Sixth component of COSO II: reporting phase}

In order to verify that there is reporting on the financing of a non-profit organization, we have carried out the following working methods:

- Examining the annual report from the viewpoint of legal funding of the nonprofit organization

- Acquisition and review of interim business analyses (e.g., offsets, deviations, reasons for deviations from the financial plan) and interim reports from the viewpoint of legal financing of the non-profit organization

We examined the content of the annual and interim reports of the organization in terms of the laws they define. We assess the contents of the annual report as appropriate, and the interim reports are inadequate because they do not exist.

\subsection{Seventh component of COSO II: assessment of information and communication}

From the meeting records of collegiums, conferences, and interviews with randomly selected employees, we find that the management is in favor of employees' initiatives regarding the improvement of individual procedures. We also get information about this from the interview with the management. We evaluate communication as appropriate.

\subsection{Eighth component of COSO II: monitoring assessment}

Internal control systems must be monitored-the quality of the system's operation over a given period should be assessed. This is done with ongoing monitoring activities, special assessments, or a combination of both [10].

There is also a special evaluation, which is mandatory by law: this is the so-called submission of the statement on internal control of public finances, which is given by non-profit organization $\mathrm{X}$ as a budget user once a year to state institutions together with the annual report. The president of the non-profit organization takes into account the findings of other controls, based on the last internal auditor's report. Based on these facts, we evaluate monitoring as appropriate.

\section{Reporting on internal audit}

We report on the results of the internal audit on a regular basis and at the end of the audit. The purpose of regular reporting is to inform the auditee about the problematic findings of the internal audit, which the auditee can abolish immediately. Upon completion of the internal audit, we draft the audit report.

The auditor prepares the draft audit report. The draft contains essential findings and recommendations. These recommendations may include an indication of the recommended key vehicle for the implementation of recommendations and the classification of the recommendation according to their assessed relevance. For example, the auditor's assessments can be critical, very important, important, and desirable.

The draft audit report shall inform the responsible persons of the key organizational units. They are then invited to coordinate the content of the draft audit report. 
Upon receipt of the draft audit report, the recipients have 10 working days to make written proposals for its alignment. This procedure is necessary in order to avoid misunderstandings or to clarify any differences between the findings of internal auditors and any new evidence/documentation available to the persons in charge.

Proposals for the harmonization sent after the deadline are generally not taken into account in the final audit report.

A coordination meeting may also be convened in the process of coordination, in which any proposals for harmonization are further explained and discussed. The coordination meeting can be convened by e-mail or by telephone.

Below is the issue of the final audit report. This must be supported by sufficient, reliable, relevant, and useful information. It must contain essential findings and recommendations. It must cover and contain at least:

- Introduction

- A summary of the findings

- Scope and objectives of the audit

- The methods and procedures for conducting the audit

- Findings and information supporting findings and recommendations

- Templates and recommendations for the elimination of detected irregularities and deficiencies

- Temporary deadlines and deadlines for remedying deficiencies and irregularities

- If necessary, detailed explanations of the findings for each area

An opinion may also be given, which may be an assessment, finding, or other descriptions.

In the final report, we present, inter alia, findings that have been evaluated or classified according to the descriptive criteria that are presented in Table 2.

\begin{tabular}{cl}
\hline Classification/rank & Description of classification \\
\hline A-A serious defect & $\begin{array}{l}\text { Violation of legal and/or professional rules is committed intentionally or through } \\
\text { negligence } \\
\text { The violation of internal business-organizational regulations is caused intentionally } \\
\text { or through negligence } \\
\text { System error with expected high consequences. } \\
\text { Individual findings with expected high consequences }\end{array}$ \\
& $\begin{array}{l}\text { Breach of legal and/or professional rules is caused by non-punishment or due } \\
\text { diligence } \\
\text { The violation of internal business and organizational rules is caused by non- } \\
\text { punishment or due diligence } \\
\\
\text { System error with expected minor consequences } \\
\text { Individual findings with expected high consequences }\end{array}$ \\
\hline C-Recommendation & Internal audit has identified the potential for improvement \\
\hline Source: Adapted after COSO model.
\end{tabular}

Table 2.

Description of evaluation of findings. 


\section{Conclusion}

Based on the findings, we prepare the recommendations that we will include in the final audit report. We give the following opinion in relation to the audit objective on the legality of the financing of non-profit organization X: positively. Our overall opinion on the legality of financing the activities of preschool education in the public service is satisfactory, and we recommend the recommendations in Table 3.

\begin{tabular}{|c|c|}
\hline \multicolumn{2}{|c|}{ Recommendation 1: the internal audit has identified the options for remedying minor deficiencies } \\
\hline \multicolumn{2}{|l|}{ Rank: B } \\
\hline Finding & $\begin{array}{l}\text { Non-profit organization } \mathrm{X} \text { in connection with the financing of activities carries } \\
\text { out monitoring and recovery of overdue receivables but treats debtors } \\
\text { differently, as it does not have uniform recovery instructions }\end{array}$ \\
\hline Recommendation & $\begin{array}{l}\text { Prepare instructions for managing receivables that determine the rules for } \\
\text { monitoring outstanding and overdue receivables and uniform measures in case } \\
\text { of overdue claims }\end{array}$ \\
\hline Measure & $\begin{array}{l}\text { The president of the organization together with the accountant prepares } \\
\text { instructions for managing receivables, the head of the organization accepts the } \\
\text { instructions with the signature }\end{array}$ \\
\hline Deadline & 30 days after the issue of the final report \\
\hline Responsible person & President of the organization \\
\hline \multicolumn{2}{|c|}{ Recommendation 2: internal audit identified potential for improvement } \\
\hline \multicolumn{2}{|l|}{ Rank: C } \\
\hline Finding & $\begin{array}{l}\text { Non-profit organization X regarding the legality of financing activities does not } \\
\text { have established regular interim reporting on the state of risk management, } \\
\text { internal control, and internal auditing }\end{array}$ \\
\hline Recommendation & Establish quarterly reporting \\
\hline Measure & $\begin{array}{l}\text { The management should report quarterly on the state of the risk management } \\
\text { and internal control in colleges with employees, reports annually on the } \\
\text { employees' conference, and reports annually on the findings of the internal } \\
\text { audit }\end{array}$ \\
\hline Deadline & 90 days after the issue of the final report \\
\hline Responsible person & President of the organization \\
\hline \multicolumn{2}{|c|}{ Recommendation 3: internal audit identified potential for improvement } \\
\hline \multicolumn{2}{|l|}{ Rank: C } \\
\hline Finding & $\begin{array}{l}\text { Non-profit organization } \mathrm{X} \text { in relation to the financing of activities does not } \\
\text { have regular monitoring of the achievement of objectives and of the interim } \\
\text { reporting on the achievement of objectives }\end{array}$ \\
\hline Recommendation & $\begin{array}{l}\text { Preparation of quarterly reports on the achievement of goals and monitoring of } \\
\text { the planned and realized business results that enable business analysis and } \\
\text { immediate action in the event of failure to achieve goals and to solve problems }\end{array}$ \\
\hline Measure & $\begin{array}{l}\text { Installation of system solutions into a computer program for printing monthly } \\
\text { reports and business analysis, which the accounting officer regularly provides } \\
\text { to the director on a monthly basis }\end{array}$ \\
\hline Deadline & 60 days from the issuance of the final report \\
\hline Responsible person & President of the organization \\
\hline
\end{tabular}

Table 3.

The recommendation after internal auditing 
If we find that certain measures and recommendations from the audit report were not carried out due to various possible causes and thus did not eliminate the deficiencies, we conclude that organization $\mathrm{X}$ accepts the risk which it does not control. In this case, the internal auditor carefully examines the risk management acceptance. The management of an organization may refuse to implement recommendations or measures if it considers that additional control procedures which, owing to the aforementioned recommendations or measures, would have to be linked to excessive costs. If, according to the internal auditor, the risk adopted by the management due to the non-establishment of additional control procedures is not acceptable, further discussion is needed between the internal auditor and the president of the organization. If there is still no consensus on accepting the residual risk, the internal auditor should inform the founder of the organization, which is the supervisory body of the non-profit organization, about this.

The limitations of the research are:

- The research is the case study, and we focused only on one non-profit organization.

- The survey is limited to one country.

- The survey is limited on the internal audit's legislation of the specific country.

- The limited choice of literature from the research area in the article.

For further research, we recommend to make the comparison of the financing of different non-profit organizations which have different activities and to make comparison of the internal controls of financing non-profit organizations in different countries of the European Union and outside of it.

\section{Author details}

Tatjana Horvat ${ }^{1 *}$ and Vito Bobek ${ }^{2}$

1 University of Primorska Faculty of Management, Koper, Slovenia

2 University of Applied Sciences FH Joanneum, Graz, Austria

*Address all correspondence to: tatjana.horvat@fm-kp.si

\section{IntechOpen}

(C) 2020 The Author(s). Licensee IntechOpen. This chapter is distributed under the terms of the Creative Commons Attribution License (http://creativecommons.org/licenses/ by/3.0), which permits unrestricted use, distribution, and reproduction in any medium, provided the original work is properly cited. (c) BY 


\section{References}

[1] Helmig B, Jegers M, Lapsley I. Challenges in managing nonprofit organizations: A research overview. Voluntas: International Journal of Voluntary and Nonprofit Organizations. 2004;15:101-116. DOI: 10.1023/B: VOLU.0000033176.34018.75

[2] Vidovič Z, Milatovič J, Hren M. Nadzor nad Porabo Proračunskih Sredstev. Ljubljana: Slovenski Inštitut za Revizijo; 2001. p. 74

[3] Rules on the Functioning of the Internal Audit Service in the Direct User of the Budget of the Republic of Slovenia. 2011

[4] Koletnik F. Notranje Revidiranje. Ljubljana: Slovenski Inštitut za Revizijo; 2007. p. 306

[5] Koletnik F, Kolar I. Forenzično Računovodstvo. Ljubljana: Zveza Računovodij, Finančnikov in Revizorjev Slovenije; 2008

[6] International Standards on Internal Auditing. 2013

[7] Vezjak B. Vloga notranje revizije pri upravljanju, ravnanju s tveganji in njihovem obvladovanju. In: Gradivo za Izobraževanje za Pridobitev

Strokovnega Naziva Preizkušeni Notranji Revizor. Predmet: Notranja revizija. Ljubljana: Slovenski Inštitut za Revizijo; 2011

[8] Horvat T. Internal Audit of the Agriculture Educational Institution. Krasnoyarsk; 2018

[9] Koletnik F. Forenzični Vidik Notranjega Gospodarskega Revidiranja. Gradivo za Izobraževanje za Pridobitev Strokovnega Naziva Preizkušeni Notranji Revizor. Predmet: Notranja revizija. Ljubljana: Slovenski Inštitut za Revizijo; 2010
[10] Cukon-Mavec N. Priprava Samoocenitve pri Neposrednih in Posrednih Proračunskih Uporabnikih. Zbornik Referatov 8. Izobraževalni Seminar o Javnih Financah in Državnem Revidiranju. Portorož: Zveza Ekonomistov Slovenije; 2006. pp. $147-160$ 
Section 5

\section{Recruitment in Non-Profit Organisations}





\title{
Connect-Active: An Innovative Recruitment Model for Potential Volunteers in Nonprofit Organizations
}

\author{
Bernadene Erasmus and Peter J. Morey
}

\begin{abstract}
The challenge to improve the recruitment and sustainability of a strong volunteer force within nonprofit organizations gains momentum at a time when the impact of a worldwide ageing population has the potential to stretch community services, which are heavily reliant on this "free resource," to the limit. Adroit management practice becomes critical within a complex environment in which a “one-size-fits-all” strategy is obsolete. This study of a faith-based hybrid organization in Australia uses a cross-disciplinary, multidimensional approach to develop the connect-active model (CAM) for volunteer recruitment strategy. Facilitated by a visual tool, the model depicts the interrelated and multi-faceted elements impacting on the initial volunteering process: recruitment. The proposed chapter will discuss an innovative and individualized approach to volunteer recruitment with the aim of increasing volunteer numbers in nonprofit organizations.
\end{abstract}

Keywords: volunteering, faith-based, recruitment, management

\section{Introduction}

Connection: The concept embodies a pervading strand representing every strata of human experience, from the umbilical cord to scientific neurons and the theories of being. Connection to the micro, meso and macro levels of life contains, within its essence, the potential for individuals and society to sustain wellbeing. Disconnection, on the other hand, a startling phenomenon of contemporary living, bears within it, seeds detrimental to society's welfare.

A growing awareness of the impact of disconnection has resulted in increasing awareness in diverse spheres of the need to establish reconnection. Books with titles such as Lost Connections [1]; YouTube conversations with the CEO of Amazon, Jeffrey Bezos; and even Disney cinema themes highlight the need to address human connection. This issue is no less relevant to the life of nonprofit organizations.

It is in direct response to the challenge faced by nonprofit organizations to connect and retain volunteers, in essence the life-blood of many nonprofits, that this study was launched. In order to gain understanding of actual elements impacting the phases of volunteer experience, a mixed method design was adopted to explore the factors that influence the recruitment, experience and retention of a sample 
of faith-based volunteers at an Australian hybrid organization. Results led to the development of the connect-active model (CAM) which identifies actuators as real-time connectors to positive recruitment. The model forms part of a larger study which incorporated all phases of the volunteer experience. In this chapter, the focus falls on the initial stage: recruitment. The chapter starts with a sketch of the volunteering context before discussing the individual actuators that impact on the connection of potential volunteers to volunteering service as illustrated in the CAM model. The discussion concludes with a list of practical recommendations aimed at enhancing effective volunteer management with particular reference to the initial phase: recruitment.

\section{Context}

The role of volunteers in societies which are facing the impact of a worldwide ageing phenomenon is gaining momentum. Reports from many countries, starting to come to grips with providing basic structural foundations to cope with the challenges associated with ageing citizens, indicate that current infrastructure may not support the opportunities that increased life expectancy potentially creates. A recent article in Time magazine (February, 2019) predicts that by 2050, 330 million Chinese will be 65+ years of age [2]. The article references the chairman of Stirling Finance Ltd., Stuart Leckie, who regards it as the "No. 1" economic challenge of the future. By 2030, 20\% of Americans will have reached retirement age, outnumbering the number of children for the first time in history. Data from the Australian Bureau of Standards [3] mirror these global trends. In June 2014, 15\% of the Australian population was aged 65 years and older. This cohort is estimated to reach between 11.5 and 18.1 million by 2101 . In addition, the number of people in Australia aged 85 years and older is expected to triple in less than 25 years. Such is the scale of the challenge that the World Health Organization (WHO) has called on all decision-makers, practitioners and researchers to increase the focus on addressing the profound consequences of global ageing on society as well as on the individual.

The implications of the abovementioned statistics mean that on international and national fronts, governments are facing shrinking tax bases along with increasing community needs. In an attempt to meet these escalating social service demands, attention is becoming focused on nonprofit organizations which generally comprise large contingents of "free" resource in the form of volunteers. The significance of nonprofit organizations as key players, seen distinct from for-profit organizations, is gaining momentum as their potential contribution to society is recognized [4-6]. In view of these escalating social needs, there is a growing trend for nonprofit organizations to provide services which were traditionally the responsibility of the government [7-12].

\section{Nonprofit challenges}

The nonprofit sector, however, has challenges of its own. The nature of these challenges is well documented in the literature [4, 13-15]. They include a move to professionalism, decreased government funding and a growing dependence on a voluntary work force. In fact, the literature suggests that nonprofit organizations, in general, would struggle to operate without volunteers [16]. Volunteer management, however, has evolved considerably from the erstwhile approach of management principles based on goodwill and informality. In a contemporary setting, many 
nonprofits consist of a diverse composition of workers ranging from full-time employees, part-time volunteer workers and non-paid volunteers. Management of this diverse range of workers means that nonprofit organizations will not retain volunteers if they are treated as a homogenous, well-meaning group of amateurs. Leaders and coordinators will need to incorporate an awareness of diversity including volunteer trends, generational and cultural differences and worker classification. In order to recruit and retain individuals who are not primarily motivated by financial initiatives, it has become crucial for volunteer management to find approaches that are relevant and effective if they are to retain people who give of their time freely and mostly for altruistic reasons.

\section{The functional approach}

One area of enquiry with potential to increase insight into the recruitment and retention of volunteers involves the consideration of the underlying social and psychological motivations of volunteers. Employing a functional approach, the volunteer function inventory, VFI [17], is an internationally verified survey instrument which identifies six underlying volunteer motivational functions associated with the initial phase of volunteering. Despite its wide application in motivational research, however, the VFI is essentially of generic relevance, and even in the view of Clary et al. [17], there may well be variation in the number and type of functions in varying contexts and volunteer type.

To address this issue, Erasmus and Morey [18], in a previous paper, selected a functional approach to test the applicability of the VFI to the initial motivations of a sample of faith-based volunteers at a nonprofit hybrid organization in Australia. For this context, four factors emerged as significant underlying social and psychological motivations for volunteering. The four-factor motivation model that emerged included three of Clary et al.s [17] VFI functions: values, social and career. The fourth factor consisted of a combination of the elements of Clary et al.s enhancement and understanding factors. Analysis suggested that the themes inherent in these items related to a real-world construct labelled enrichment. The enrichment factor may be described as opportunity for volunteers to learn and grow personally in their understanding of themselves and the world and to use this experience to benefit the lives of others. The final four-factor structure is considered reliable given that each factor has an allocation of five or more items with loadings $>0.5$ and internal reliabilities of 0.836 for enrichment, 0.828 for career, 0.767 for social and 0.640 for values. The new structure was titled the faith-based volunteer motivation (FVM) scale, and its validity was tested against levels of volunteer satisfaction for this sample of volunteers.

Research further suggested that in respect of volunteering, there might be initial motivating factors other than the six functions proposed by Clary et al. [17]. Wilson [19] in a review of volunteering research indicated that one of the limitations of Clary et al.s VFI was that the set of motivation factors outlined was neither exclusive nor exhaustive. Based on these views, additional functions were added to the FVM, and these were found to have particular relevance for this context. Two items from Esmond and Dunlop's volunteer motivation inventory (VMI) [20] were added: reactivity and reciprocity. Reactivity outlines the response of volunteers to critical events in their past, while reciprocity represents the desire of volunteers to "give back" to the community in the form of service. A third motivator, value congruence, based on the work of Wright and Pandey [21], was included to reflect the alignment of individual volunteer values with those of the organization. 


\begin{tabular}{lc}
\hline Motivational functions & Scale ranking \\
\hline Values & 1 \\
\hline Values congruence & 2 \\
\hline Enrichment & 3 \\
\hline Reactivity & 4 \\
\hline Social & 5 \\
\hline Reciprocity & 6 \\
\hline Career & 7 \\
\hline
\end{tabular}

Table 1.

Ranking of initial FVM and non-FVM motivation factors.

A scale was generated for each of these non-FVM motivational functions by calculating the mean of the respective responses. The scales were all scored on a four-point Likert scale. A scale mean of 2.5 or greater would indicate that a majority of this sample agreed or strongly agreed that the function was a strong motivator for their initial volunteer decision. Factor analysis and correlational analysis which indicated that the correlation coefficients between the respective non-FVM motivation factors were all below 0.287 would suggest that these factors are distinct and relevant motivators for these faith-based volunteers.

The mean of the FVM motivation factors and the additional non-FVM motivation factors was determined, and these means were compared to generate a ranking of the respective motivating factors impacting the initial stage of the volunteering process for faith-based volunteers. The combined initial motivation factors ranking is illustrated in Table 1.

\section{Call for more}

Although the value of reliable and valid survey instruments is acknowledged, it is recognized that there are potentially relevant categories which are not specifically covered in this paradigm [22]. One such category is religion which, even when taken into account via survey research, may potentially oversimplify the analysis of complex phenomena such as spirituality. Voices in the literature have called for further studies employing a qualitative orientation to ensure richer and more in-depth insights by incorporating the voice of volunteer experience [23, 24]. In order to address this issue, this research adopted a mixed method approach which included both a survey instrument and semi-structured interviews in a concurrent design. Results from the quantitative and qualitative orientations were synthesized in a quest to gain a more holistic insight into the research phenomena.

In addition, a holistic approach necessitated a consideration of the multidimensional nature of volunteering. In fact, volunteering has been described as an "inherently multi-dimensional phenomenon" ([25], p. 20). Coupled with a multidimensional approach then, this research aims to inform a diversity of stakeholders about factors which may enhance effective management practice. The chapter forms part of a wider study which incorporates all phases of the volunteer experience: recruitment, experience and retention. In this section, however, focus will principally be on the initial phase: recruitment. This division of phase is purely conceptual as themes and actuators interplay in a complexity of ways across all phases. 


\section{Recruitment}

For the purpose of this study, the volunteering process is conceptualized as follows: recruitment, experience and retention. This broad framework is based loosely on the classic model developed by Omoto and Snyder [26]. Their model encompasses three broad and sequential phases: antecedents, experiences and consequences. The selection of a more generic model was deemed a good fit as it emerged naturally from the data, which allowed for greater flexibility and enabled the research to retain an essential focus on managerial practice.

The recruitment phase encompasses the initial phase in which volunteers are attracted to an organization and focuses on the elements that impact their decision to volunteer. The initial stage of the volunteering process which includes management recruitment strategies has received considerable attention in the literature. The significance is highlighted by authors such as Wilson [19] who writes "The search for the antecedents of volunteerism is a search for the cause of volunteerism." This pre-eminence may be attributed to the conundrum which continues to surround the initial decision to volunteer. While there appears to be less mystery surrounding the reasons for individuals to seek paid employment, the answer to why individuals give time willingly to benefit others without primarily seeking financial gain tends to remain open-ended [25].

\section{The connect-active model}

From the converged results which emerged from this mixed method research, a model was developed which outlines the interplay of themes impacting the initial phase of volunteering: the connect-active model (Figure 1). This visual model illustrates the significance of the interrelation between elements of themes as well

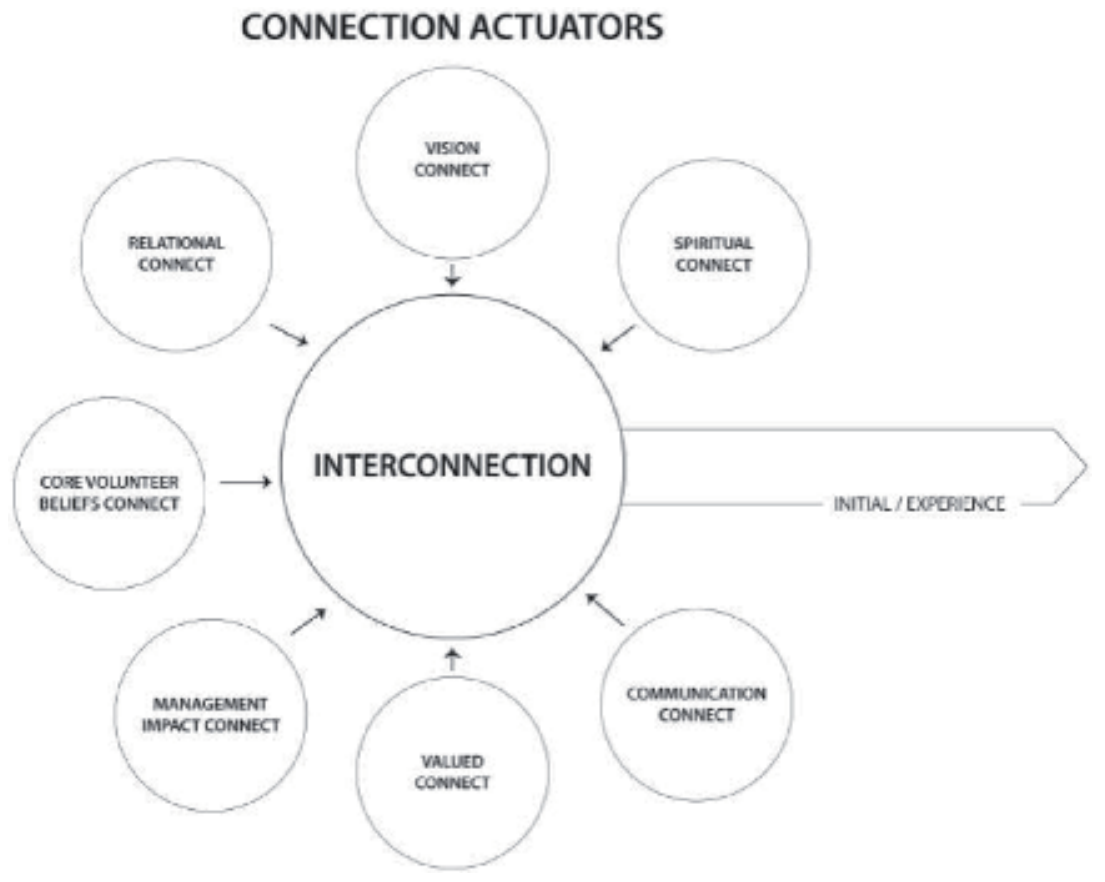

Figure 1.

Connect-active model (CAM) for recruitment. 
as the interconnection between themes themselves. Actuators are defined as distal factors which, when facilitated by management practice, impact recruitment and have the potential to perpetuate connection. To facilitate understanding, actuators are discussed individually in the section that follows. In practice, however, these actuators co-exist in a multidimensional and complex interplay impacting on the recruitment of faith-based volunteers. The following connecting actuators, identified as having primary impact on volunteer connection, will not be discussed in any hierarchical form as they are deemed to be of equal weight in impacting the recruitment of volunteers.

\section{Core belief connect}

The core belief actuator may be defined as a pathway incorporating essential individual values which represent the scaffolding of the perspective worldview of the volunteers. For these faith-based individuals, the opportunity to serve others and the potential for personal learning and spiritual growth, as well as the chance to enhance life experience and self-concept, emerged as principal values impacting on their decision to volunteer. This finding complements a study by Fitzpatrick et al. [27] who propose that prime components of volunteering include personal growth and learning. Motivation, based on organizational opportunity for growth and learning, has also been noted by Bassous [28].

In general, these participants adopted an altruistic approach to volunteering. Recurrent phrases, such as "for others" and "for the benefit of people," were evident in conversation with this sample. They perceived the essence of volunteering to mean service with the potential to positively impact the lives of others, suggesting that they viewed volunteering essentially in altruistic terms. This view concurs with that of a study by Bassous [28] who found that most faith-based participants in his study associated with the concept of altruism. It also concurs with the finding that Australian volunteers in general serve primarily for other orientated reasons [29].

These views were prominent both in the interviewing process and in the high ratings given to non-FVM motivations in the survey phase: reactivity (helping others because of personal difficult experiences) and reciprocity (helping for mutual benefit). An opportunity to "do good" and give back to the community in the form of service to others was regarded by this sample of volunteers as a decisive reason for deciding to volunteer. This view was complemented and expanded in the qualitative data to include an understanding of initial motivation in the context of participants' perception of spirituality. In conversation, these faith-based participants perceived reciprocity not only in terms of giving back to people but also to God.

The sample in this study found no conflict with their faith beliefs in embracing volunteering as an opportunity for personal growth and learning which they understood in relation to the development of skills and knowledge, the broadening of world experience and the potential for spiritual maturation. For the majority, learning and growing were not regarded as a self-directed, selfish ambition but a means of improving self for the service of others. Consequently, a volunteer course in Japanese culture was regarded as beneficial both for individual development and as potentially increasing effectiveness during an upcoming Japanese mission trip. The exception was advocated by several younger members for whom career opportunities formed a primary motivation. Some younger individuals signed up to volunteer in the hospitality division with the aim of training as a barrister which potentially increased their employability in paid positions. For this sample as a whole, across 
generation and gender, however, the value of personal growth in terms of increased understanding of other cultures and the potential to grow in spiritual maturity were rated highly and linked to satisfaction with volunteering experience.

\section{Mission connect}

Personal beliefs and values were found to be closely aligned to mission congruence in this study. Results from the quantitative phase, in particular, indicated that value congruence was a strong initial motivating factor for these participants. The alignment of personal values with those of the organization was perceived to frame an important element in the initial decision to volunteer at a specific organization. In this study the concept of mission congruence was somewhat distinctive from value congruence in that it incorporated a divine element. While value congruence was seen principally as an alignment between individual values and those of the organization, mission congruence implied a wider perception in which the vision extended to a meta-identity of a worldwide mission of serving God and people.

In this study, participants perceived that they were aligned, not only with the values of the organization which implied faith-based beliefs but indeed with the meta-vision of faith believers universally. The association with a worldwide vision, incorporated in the mission statement of the FBO where they were serving, was perceived by these volunteers to be an important factor in deciding to volunteer. Belonging to a mission, connected to something bigger than local projects, was enticing to volunteers who wanted their lives to make a difference on a global scale. This insight brought some illumination to the fact that these faith-based volunteers placed relatively less emphasis on organizational commitment. Initially this result appeared incongruent, given the importance of this phenomenon in the literature [30]. When considered in the context of the significance of participants' primary commitment to personal faith and to a meta-vision, this result is less surprising. This has implications not only for the initial stage of volunteering and recruitment but also for the other phases: experience and retention.

What potentially sustains volunteering for this sample, therefore, is a commitment not only to the organization in which they serve but more so to a strong link with their personal faith call and a connection to a worldwide mission. This sense of commitment to a universal vision, a bigger picture, potentially constituted a significant factor in sustaining connection and by implication, impacting positively on intention to remain in service. It may be concluded that for this sample of faithbased volunteers, a spiritual element is inextricably part of the mission connection. Consequently, establishing vision congruence in the initial phase is important but not sufficient for promoting sustainability. Volunteer management is advised to continually ensure that volunteers are connected to the wider mission statement of the FBO.

\section{Spiritual connect}

Spirituality, as a distinctive motivating factor, emerged strongly from participant interviews in this study. Insight gained into the role of spirituality, indicated in all stages of the volunteering process, contributed to a better understanding of faith-based volunteering in general. The significance of the spiritual function finds complement in the view of Pargament [31], who proposes that the spiritual function is the most salient motivating factor for faith-based individuals.

In this study, participants described spirituality essentially as centred on their experience with a relationship with the divine. For this sample, this definition was 
significant in distinguishing the understanding of spirituality from that of religiosity which they perceived as relating primarily to a sense of legalism. The call to serve, perceived as a universal tenet of faith teaching, was individualized through personal directive. Participants referred to this as "the call" and ascribed "answering the call” (putting it into practice) as a response to a revelation based on relationship and not as a result of legalistic obligation. The call of God was operationalized in diverse ways in varying pathways through the course of a personal lifespan. Although the course of the call might vary in diverse environments and circumstances, participants ascribed an ongoing connection with the call as the mainstay of sustainability. This endorses the view that although the phases of volunteer experience may be conceptualized separately, motivations for initial, experience and retention overlap and intertwine in practice.

A sense of enjoyment and satisfaction with the volunteering experience was enhanced, for this sample, by a sense of divine affirmation. Spiritual coping, which was described as divine support and encouragement, was strongly indicated in volunteer retention. Although faith-based volunteers in this study acknowledged that principally they faced the same challenges as their non-faith-based counterparts, their way of potentially overcoming these challenges was described as being rooted in a personal relationship with God who supported them through crises and provided a way out. This sense of being connected to a divine source in times of challenge was seen by this sample to be significant in sustainability.

Another interesting finding from the data was that although the initial motivation for some participants may have been Clary et al's [17] social factor, it was spiritual motivation that was described as the main sustaining actuator by the majority of those interviewed in this study. This result is complementary to the proposal by Ozorak [32] that initial motivations are not necessarily the ones that sustain volunteering over the course of time. Volunteer management, consequently, cannot assume that initial motivations remained unchanged.

\section{Relational connect}

While the call to serve originated mostly from a divine directive for this sample, the actualization of prosocial service was invariably connected to human relations. While spirituality played a primary role in the initial volunteering process for this sample, the role of meaningful human relations too played a pivotal role in all stages of the volunteering process. In the survey results, participants returned a high rating for the initial motivation of the VFI social function which is described as essentially being connected to others and feeling endorsed by significant others. An overview statement proposes that the connection of individuals to a personal divine relationship, as well as meaningful relationships with a diversity of human agencies, may be regarded as representing principal actuators in engaging potential volunteer recruits.

In the initial phase, several relational threads were identified as necessary to connect potential individuals with volunteering service. These included church members, family, friends, social networks and leadership relationships. As members of the church, some participants were socialized into organizational norms and practices ahead of the decision to volunteers. One young adult male volunteer said:

So it was just what you did at church-you served.

The influence of family emerged as another important influential connector in promoting a positive response to volunteering. This result echoes the views 
of Musick and Wilson [33] who advocate the importance of understanding "the dynamics of the household" in volunteer practice. A young female participant attested to the positive influence of family in her decision to volunteer:

Mum and dad taught us that routine (to volunteer) and they planted that in us, you know. Yeah, yeah, I think it's just something in the family.

The influence of culture in which family traditions are embedded provided a fascinating aspect of factors impacting volunteering. This is an area of study that requires further investigation. Owing to the limitation of this section, the issue can only be highlighted and not discussed at any length. One example, however, may suffice to ignite interest. In pursuing the theme of culture and family as volunteer connectors, one young male volunteer from the Pacific Islands reflected:

\section{So I think it's really embedded in me culture-wise: To see my mum and dad do stuff like that. You could probably say its "volunteering" but I never saw it as that. Just helping, helping out, yeah.}

Among the younger volunteers, several said that they had been invited to join by peers. In addition, the role of social media as an emerging connector requires attention in future studies. For all age and gender considerations in this study, personal relationships were regarded as a significant connector in the antecedent as well as the initial stage of volunteering. In general, all participants confirmed that the enjoyment of making new friends, the support from existing friendship circles and the potential to realise a sense of accomplishment through group efforts were significant factors impacting the volunteering experience. Social networks in the initial stage were seen to represent varying levels of relationships. The identified pathways connecting individuals to volunteering through relating and belonging in this study have much in common with the community-based routes described by Omoto and Snyder [26].

There was a general expectation among the faith-based volunteers at the FBO in this study that leadership and management cultivate relationships with volunteers, be prepared to sacrifice time and energy in connecting with volunteer teams and be seen publically to volunteer themselves. In addition, participants stressed the importance of having the right leader in the current complex volunteer management environment. They acknowledged the challenge faced by management called to lead teams comprising both unpaid and partly paid volunteers. For their part, volunteer management and leaders at the FBO expressed an awareness of these expectations and endorsed the significance of fostering relationships with volunteers. A young female volunteer youth leader summed it up as follows:

\section{Everything has to be done and spoken through relationship.}

Within the current complexities of contemporary volunteer management and the ongoing challenge of fostering positive relationships, both management and volunteers acceded to the importance of recognizing the concept of belonging as a vital connecting link in the understanding of positive volunteering experience. All participants, including volunteers, management and leadership indicated that they made a clear distinction between belonging to a club and a deeper connection of belonging to a "family" of faith-based volunteers. Despite adopting a sense of belonging as a vital part of the volunteer management philosophy, fostering a sense of belonging for the younger generation potentially posed a more complex challenge. A young adult male youth leader explained: 
So, you know, a young person doesn't have to volunteer somewhere to belong. They can belong on an internet forum or they can get that on their iPhone. I think we are looking at an age where interaction is not a necessity for young people to belong. So, we have to create something that is real.

The importance relegated to the development and maintenance of "real" personal relationships in the volunteering process emerged from the data for all gender and age categories. The value attached to relational connection by females in this study was not a surprise, given that the preference given by female volunteers to relational roles has been documented in the literature [34]. What was a little more surprising was the relatively high rating given by males to the social function in this study. This priority was recorded not only as an initial motivator but also as an ongoing source of connection, particularly as indicated by mature male volunteers who spoke of the importance of the "bloke connection" in task accomplishment. A link between males and the social function has also been noted in a study by Stukas et al. [29].

The significance of actively fostering relational connection and a sense of belonging is underscored when the converse is considered. Volunteers who had left the FBO had done so as a result of becoming disconnected from peers, from leadership and from the organization in general. Participants expressed the view that if individuals were not serving in some capacity, they found it difficult to maintain connection and invariably left feeling devalued. Creating a sense of being valued is initiated in the recruitment phase. Empirical evidence supports the view that personal invitation remains the most effective form of increasing decision to volunteer. It is a sense of being acknowledged as someone who has potential to make a difference that creates a feeling of being valued according to volunteers who were interviewed.

\section{Valued connect}

In addition to the significance ascribed to a feeling of being valued by God, positive personal relationships with volunteer managers and leaders in particular were seen to play an important role in fostering a sense of personal value. For this sample, this perception of being valued included not only recognition for the skills and service offered but also affirmation of the individual per se. A distinction was therefore made between acknowledgement (reward and recognition) and affirmation (personal attributes). Participants described the difference as being between "what I do" and "who I am." For these volunteers, acknowledgement could be expressed through diverse forms of recognition and reward and be delivered through a variety of human agents providing it conveyed a sense of being valued. Cultivating a culture where volunteers experience a high level of being valued from the initial phase posed the strongest counter strategy to a "commodity" culture in which volunteers felt acknowledgement only for the service rendered.

Although the majority of participants placed primary importance on intrinsic reward, they did not discount extrinsic reward in the form of small tokens of appreciation. Further, there was no evidence to support the view that the expressed need for acknowledgement suggested any "crowding out" effect for this sample. This is in line with the findings of Bassous [28] that intrinsic motivation, which is closely aligned to personal faith, may be enhanced by external factors if extrinsic reward is effectively administered. In the current study, these tokens of recognition were regarded as non-calculating bonuses aimed at expressing a sense of being valued and not as ego-enhancing reward. In summary, participants 
expressed the view that in accepting these rewards, they were being recognized for their volunteering as opposed to volunteering for recognition. Consequently, it is suggested that volunteer management actively work to incorporate both acknowledgement and affirmation in communicating value to volunteers throughout the volunteer experience.

\section{Communication connect}

The role of relevant, contemporary language in the recruitment of volunteers, in enhancing volunteer experience and in strengthening future commitment, emerged from the data as having significant subjacent impact on the volunteering process. This is a broad theme which incorporates subthemes of metaphor and meaning and has been extensively discussed in the wider thesis and in the literature. This section will only touch on two aspects of the phenomena: definition and relational language.

Feedback from focal meetings and a reading of the data indicated a general acceptance of the current generic definitions of volunteering such as the 2015 definition offered by Volunteering Australia:

Volunteering is time willingly given for the common good and without financial gain.

Participants felt, however, that there would be a stronger connection if definition included salient elements of volunteering type in specific context. These faithbased volunteers suggested that the incorporation of words such as God, vision and helping others would strengthen identification and foster connection with their volunteering experience. The following definition compiled by participants of the focal groups reflects this view:

Faith-based volunteering is helping, supporting and building the vision of God collaboratively to extend the kingdom of God.

Relational language was shown in the data to be of significance in connecting and sustaining a sense of social cohesion for all participants but particularly for the younger members in this sample. In conversation, youth leadership at the FBO emphasized that connection with youth "had to be relational." In addition, there needed to be a constant assessment of traditionally relevant volunteering terminology. In this context, it emerged that in some instances, youthful members considered the term "volunteering" to reference community work, while "service" was perceived to be related to church-related volunteering activities. One youth leader advised that for younger members of his team, the word "volunteering" was "just not a young person word."

Overall results suggest that volunteer management can no longer assume the relevance of traditional terminology relating to volunteering. Consequently, it is recommended that an awareness of language relevance be borne in mind to ensure continued connection between volunteer nomenclature and volunteer experience. Results from this study complements strongly the view of Sider and Unruh [35] to the effect that a "one-size-fits-all language yields one-size-fits-all-policies" (p. 110). Conclusion from the current research indicates clearly that a "one-size-fits-all" volunteer management strategy has been given the thumbs down in favour of management diversity based on connect-actual relational links established through contemporary relevant language. 


\section{Management connect}

It appeared evident that potential volunteers envisaged some form of relational connection with volunteer leaders and managers in the course of their service. Further, they expected leaders to connect them to an experience where they could potentially make a difference in the lives of others and at the same time learn and grow as individuals. In principle, they supported an environment in which change, growth, the suggestion of new ideas and participation in decision-making affecting volunteer management were encouraged. Before registering interest, potential volunteers appeared to seek confirmation that they could expect freedom to voice opinion and to be granted some form of self-governance.

These faith-based volunteers in general were happy with autonomous practices within a form of structure based on a family model adopted by the FBO. In this model, leadership encouraged the idea of mentors, with similarity to the concept of parental guidance, rather than authoritarian voice. The perception that they would be connected to volunteering as members of a "family" rather than being regarded as "unpaid workers" meant there was variance in the way these volunteers expected the structure to operate. This could lead to interesting dynamics in the way volunteer managers negotiate these varying expectations. The issue is only highlighted here and needs further investigation to increase insight.

The importance of identifying initial motivating functions of faith-based volunteers and matching these to initial volunteering activities in order to promote potential satisfaction with experience has been referred to in a previous paper [18]. It is reiterated here as a significant connecting exercise. The efforts of management to connect potential volunteers to a "good fit" volunteering task is perceived by these participants to indicate an expression of valuing the individual.

\section{Conclusion}

The development of the connect-active model for volunteer recruitment has been inspired by the desire to join the commendable efforts of representatives from a diversity of sectors, to foster connection and sustainability in volunteerism. In this respect the role of nonprofit organizations is assuming a pivotal place in meeting the needs of increasing ageing communities. Volunteers who already represent a significant slice of the answer to meeting community needs pose an even greater potential for addressing future challenge-but only if their value is recognized and operationalized in effective management practice. The connect-active model (CAM) volunteer recruitment highlights the need to acknowledge specificity of context by identifying underpinning metaphor and developing actual pathways of connectivity to ensure a best fit between recruit and organization. By adopting a pragmatic lens, it is hoped that the application of the theoretical framework to a practical model will facilitate volunteer management to promote and sustain an irrefutably valuable social resource: volunteers.

\section{Recommendations}

In line with the overarching paradigm of pragmatism adopted in this study, results from the data suggested practical recommendations for enhancing effective management practice for faith-based volunteers in a specific context. Wider application awaits further enquiry, but it is proposed that some suggestions may potentially have relevance for other volunteer management contexts. Further, it 
supports a basic assumption of this research which adopts the Lewinian dictum that there is nothing so practical as good theory. The following recommendations are selected from a wider directory in the main study and will focus on the initial phase of volunteering, recruitment.

- Management recruitment recommendations strategies should recognize the pivotal role of spiritual motivation for faith-based volunteers. Spiritual maturing is incorporated in their perception of serving in volunteering activities.

- Identification of an individual call may facilitate matching volunteer activities with volunteer motivation.

- Measures should be put into place to identify individual underlying motivations in recruitment in order that these motivations may be matched with volunteer activity from the start. If, for example, the social function is dominant, then the volunteering activity should incorporate opportunity for meeting and connecting with others.

- Management cannot assume, however, that initial motivations will remain as the constant connecting factors throughout the volunteering process.

- Decisions to volunteer stem primarily from personal invitation delivered by pre-established contact. Volunteer recruiting teams are advised to foster social contact and pursue social connection prior to extending a personal invitation.

- It is essential in the current environment where the majority of potential volunteers are time strapped, to tailor volunteering to suit individual needs.

- Volunteer expectations need to be clearly identified and clarified. Unrealistic expectations should be addressed prior to commencement of volunteering service.

- Volunteer expectations in terms of opportunity to learn and grow and to enrich their lives and the lives of others should be incorporated into recruitment drives.

- Leaders and managers should actively facilitate synergy between individual values and that of the organization in order to foster value congruence.

- Time and effort should be allocated to identifying the underpinning metaphor of specific organizations and ensure the terminology used in mission statements is sufficiently wide and appropriate to accommodate all volunteers on the spectrum of potential recruits in order to foster mission congruence.

- Recognition should be given in recruitment drives to the emphasis required for diverse age groups: Younger members are more likely to be recruited through relational language, and for many in this cohort, career-focused activities will be a strong drawcard. Older individuals are more likely to be attracted by the opportunity to meet and serve others, enhancing personal growth. For the more mature recruits, traditional terminology and definition may still be the relevant connector.

- Cross-cultural diversity necessitates the inclusion of leaders who are culturally aware of the definition of volunteering terms as they pertain to cultural 
diversity and ensure that the meaning of these concepts is clearly communicated in recruitment language.

- Where possible, management should incorporate family packages and shortterm mission projects in their recruitment strategies.

- Volunteer management should clearly detail operating structures within which volunteers may exercise autonomy.

- Volunteers feel valued when they are both acknowledged and affirmed. Management should explore a diversity of creative means to ensure that volunteers feel valued.

- Introducing and managing a diverse and individualized connecting strategy for potential volunteers may pose additional weight on an already overloaded management team. The CAM approach aims to facilitate volunteer recruitment through clearly identified actual pathways.

Connection: It's contemporary; it's critical and it's complex. Nonprofit organizations cannot escape the impact. With the aid of practical models for enhancing recruitment such as the connect-active model for volunteering, leaders and management within the sector are offered a tool with the potential to facilitate their role in connecting a vital source of service with the welfare of the world's communities.

\section{Author details}

Bernadene Erasmus* and Peter J. Morey

Avondale Institute for Tertiary Education, Charles Sturt University,

New South Wales, Australia

*Address all correspondence to: berasmus@bigpond.com

IntechOpen

(C) 2019 The Author(s). Licensee IntechOpen. This chapter is distributed under the terms of the Creative Commons Attribution License (http://creativecommons.org/licenses/ by/3.0), which permits unrestricted use, distribution, and reproduction in any medium, provided the original work is properly cited. (cc) BY 


\section{References}

[1] Hari J. Lost Connections. NY USA: Bloomsbury; 2018

[2] Campbell C. China's Time Bomb. NY: Time; 2019

[3] Australian Bureau of Statistics. Standards. (3101.0). Canberra, Australia; 2014. https://www.abs.gov.au

[4] Briggs E, Peterson M, Gregory G. Toward a better understanding of volunteering for nonprofit organizations: Explaining volunteers' pro-social attitudes. Journal of Macromarketing. 2010;30(1):61-76

[5] Cnaan RA, Curtis DW. Religious congregations as voluntary associations: An overview. Nonprofit and Voluntary Sector Quarterly. 2013;42(1):7-33

[6] Helmig B, Jegers M, Lapsley I. Challenges in managing nonprofit organizations: A research overview. Voluntas: International Journal of Voluntary and Nonprofit Organizations. 2004;15(2):101-116

[7] Dolnicar S, Randle M. What motivates which volunteers? Psychographic heterogeneity among volunteers in Australia. Voluntas: International Journal of Voluntary and Nonprofit Organizations. 2007;18:135-155

[8] Eisner D, Grimm RT, Maynard S, Washburn $S$. The new volunteer workforce. Stanford Social Innovation Review. 2009;7(1):32-37

[9] Gage RL, Thapa B. Volunteer motivations and constraints among college students: Analysis of the volunteer functions inventory and leisure constraints models. Nonprofit and Voluntary Sector Quarterly. 2012;41(3):405-430

[10] Greenslade JH, White KM. The prediction of above-average participation in volunteerism: A test of the theory of planned behavior and the volunteers functions inventory in older Australian adults. The Journal of Social Psychology. 2005;145(2):155-172

[11] Perotin V. The voluntary sector, job creation and social policy: Illusions and opportunities I. International Labour Review. 2001;140(3):327-362

[12] Vantilborgh T, Bidee J, Pepermans R, Willems J, Huybrechts G, Jegers M. A new deal for NPO governance and management: Implications for volunteers using psychological contract. Voluntas: International Journal of Voluntary and Nonprofit Organizations. 2011;22:639-657

[13] Dover G, Lawrence TB. The role of power in nonprofit organization. Nonprofit and Voluntary Sector Quarterly. 2012;41:991-1010

[14] Hustinx L, Lammertyn F. Collective and reflexive styles of volunteering: $A$ sociological modernization perspective. Voluntas: International Journal of Voluntary and Nonprofit Organizations. 2003;14(2):167-187

[15] Jager UP, Schroer A. Integrated organizational identity: A definition of hybrid organizations and a research agenda. Voluntas: International Journal of Voluntary and Nonprofit Organizations. 2014;25(5):1281-1306

[16] Wisner PS, Stringfellow A, Youngdahl WE, Parker L. The service volunteer-loyalty chain: An exploratory study of charitable not-for-profit service organizations. Journal of Operations Management. 2005;23(2):143-161

[17] Clary EG, Snyder M, Ridge RD, Copeland J, Stukas AA, Haugen J, et al. Understanding and assessing the motivations of volunteers: A functional 
approach. Journal of Personality and Social Psychology. 1998;74(6):1516-1530

[18] Erasmus B, Morey PJ. Faith-based volunteer motivation: Exploring the applicability of the volunteer functions inventory to the motivations and satisfaction levels of volunteers in an Australian faith-based organization. Voluntas: International Journal of Voluntary and Nonprofit Organizations. 2016;27(2):509-1020

[19] Wilson J. Volunteerism research: A review essay. Nonprofit and Voluntary Sector Quarterly. 2012;41(2):176-212

[20] Esmond J, Dunlop P. Developing the Volunteer Motivation Inventory to Assess the Underlying Motivational Drives of Volunteers in Western Australia. Western Australia: Lotterywest; 2004

[21] Wright BE, Pandey SK. Public service motivation and the assumption of person-organization fit: Testing the mediating effect of value congruence. Administration and Society. 2008;40(5):502-521

[22] Bellamy J, Leonard R. Volunteering among church attendees in Australia. In: Hustinx L, Von Essen J, Haers J, Mels S, editors. Religion and Volunteering: Complex, Contested and Ambiguous Relationships. Switzerland: Springer; 2015. pp. 121-143

[23] Einolf CJ. Daily spiritual experiences and prosocial behavior. Social Indicators Research. 2013;110:71-87

[24] Holmes K. The value of volunteering: The volunteer's story. Australian Journal of Volunteering. 2009;14:1-9

[25] Hustinx L, Cnaan RA, Handy F. Navigating theories of volunteering: A hybrid map for a complex phenomenon. Journal for the Theory of Social Behavior. 2010;40(4):410-434

[26] Omoto AM, Snyder M. Considerations of community. The
American Behavioral Scientist. 2002;45(5):846-867

[27] Fitzpatrick T, Edgar L, Remmer J, Leimanis M. Job satisfaction among volunteers with personal cancer experience. Journal of Social Service Research. 2013;29(3):293-305

[28] Bassous MG. What are the factors that affect worker motivation in faith-based nonprofit organizations? Voluntas: International Journal of Voluntary and Nonprofit Organizations. 2015;26:355-381

[29] Stukas AA, Hoye R, Nicholson M, Brown KM, Aisbett L. Motivations to volunteer and their associations with volunteers' well-being. Nonprofit and Voluntary Sector Quarterly. 2016;45(1):112-132

[30] Chacon F, Vecina ML, Davila MC. The three-stage model of volunteers' duration of service. Social Behavior and Personality. 2007;35(5):627-642

[31] Pargament KI. Spirituality as an irreducible human motivation and process. The International Journal for the Psychology of Religion. 2013

[32] Ozorak EW. Love of god and neighbor: Religion and volunteer service among college students. Review of Religious Research. 2003;44(3):285-299

[33] Musick M, Wilson J. Volunteers: A Social Profile. Bloomington: Indiana University Press; 2008

[34] Wymer W. The implications of sex differences on volunteer preferences. Voluntas: International Journal of Voluntary and Nonprofit Organizations. 2011a;22:831-851

[35] Sider RJ, Unruh HR. Typology of religious characteristics of social service and educational organizations and programs. Nonprofit and Voluntary Sector Quarterly. 2004;33(1):109-134 



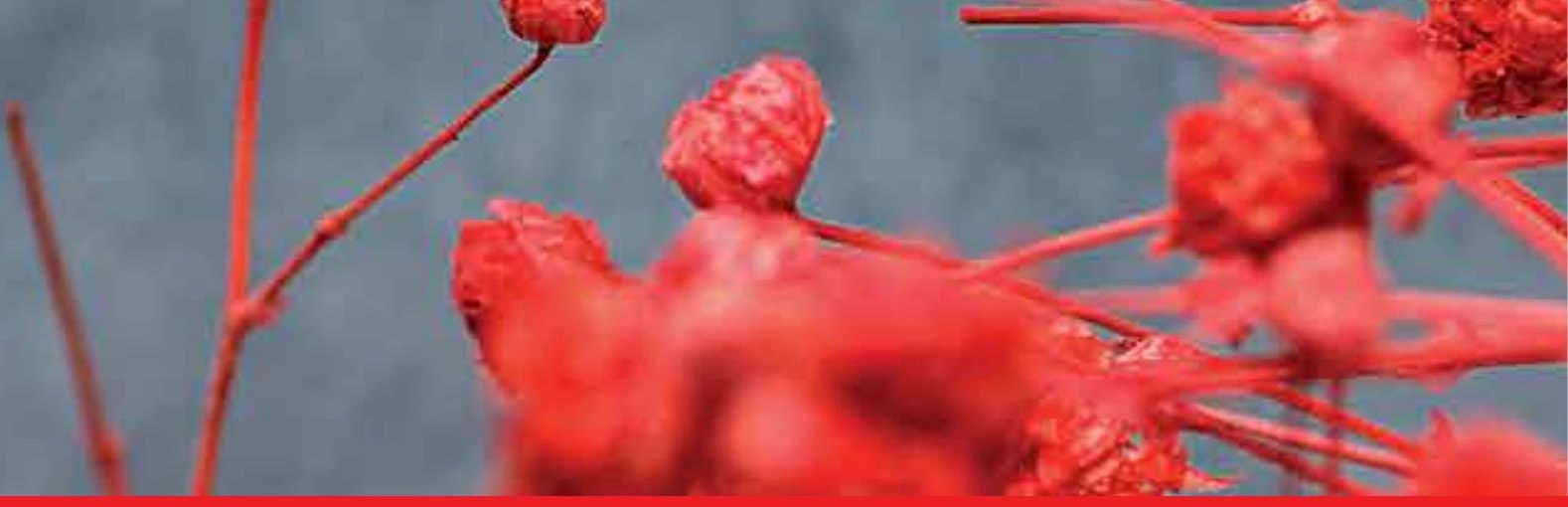

\section{Edited by Tatjana Horvat}

The volatility of the economy, political instability, and greater demands on not-forprofit organisations (non-profits) will require considerable rethinking and refocusing for many organisations. These days, non-profits evolve while attempting to regain financial ground, focusing more on workflow, fundraising, and staffing. The book

highlights the upcoming challenges, among others funding instability, with a continuing shift in funding with more grantors focusing on funding mobilisation instead of intervention. Another challenge is clustering, which is where organisations are more likely to band together with others to share overhead costs, resources, and personnel. The non-profit sector will undergo essential integrations where the free flow of data and information will be crucial. Non-profits will continue to adjust their goals and priorities to meet changing trends. While the top priority was once acquiring new donors, that has now been eclipsed by the need for non-profits to engage the community and promote general brand awareness.

Published in London, UK 